Atmos. Chem. Phys., 13, 4917-4939, 2013

www.atmos-chem-phys.net/13/4917/2013/

doi:10.5194/acp-13-4917-2013

(C) Author(s) 2013. CC Attribution 3.0 License.

\title{
The mass and number size distributions of black carbon aerosol over Europe
}

\author{
C. L. Reddington ${ }^{1}$, G. McMeeking ${ }^{2}$, G. W. Mann ${ }^{1}$, H. Coe ${ }^{3}$, M. G. Frontoso ${ }^{4}$, D. Liu ${ }^{3}$, M. Flynn ${ }^{3}$, D. V. Spracklen ${ }^{1}$, \\ and K. S. Carslaw ${ }^{1}$ \\ ${ }^{1}$ Institute for Climate and Atmospheric Science, School of Earth and Environment, University of Leeds, Leeds, UK \\ ${ }^{2}$ Department of Atmospheric Science, Colorado State University, Fort Collins, CO, USA \\ ${ }^{3}$ School of Earth, Atmospheric and Environmental Sciences, University of Manchester, Manchester, UK \\ ${ }^{4} \mathrm{C} 2 \mathrm{SM}$ - ETH Zürich, Zürich, Switzerland
}

Correspondence to: C. L. Reddington (c.reddington@see.leeds.ac.uk)

Received: 5 September 2012 - Published in Atmos. Chem. Phys. Discuss.: 9 October 2012

Revised: 23 March 2013 - Accepted: 7 April 2013 - Published: 14 May 2013

\begin{abstract}
Black carbon-containing aerosol particles play an important role in the direct and indirect radiative forcing of climate. However, the magnitude and sign of the net radiative effect is strongly dependent on the physical properties of the black carbon (BC) component of the particles, such as mass concentration, number size distribution and mixing state. Here we use a global aerosol model combined with aircraft measurements of $\mathrm{BC}$ particle number and size from the Single Particle Soot Photometer (SP2) to assess the realism with which these physical properties are predicted by global models. The comparison reveals a substantial mismatch between the measured and modelled BC size distribution over the size range of the SP2 instrument $(90-400 \mathrm{~nm}$ BC diameter). The model predicts $\mathrm{BC}$ particle number concentrations a factor $\sim 3.5-5.7$ higher than measured and a mode diameter that is $\sim 40-65 \mathrm{~nm}$ smaller than observed. More than $\sim 90 \%$ of the model particles with dry diameters $\gtrsim 260 \mathrm{~nm}$ contain BC, while the observations suggest only $14 \%$ on average. These model-observation biases in the $\mathrm{BC}$ properties are considerably greater than for the overall particle distribution, suggesting that the discrepancy is associated with model assumptions about the size and mixing state of the emitted carbonaceous particles. We expect the discrepancy in $\mathrm{BC}$ size distribution to be common among most global aerosol models, with implications for model estimates of absorption optical depth and direct radiative forcing.
\end{abstract}

\section{Introduction}

Atmospheric aerosol particles modify the global radiation budget directly by scattering and absorbing solar radiation and indirectly by modifying the microphysical properties of clouds (e.g. Haywood and Boucher, 2000; Forster et al., 2007). Carbonaceous combustion aerosol particles are emitted directly into the atmosphere as a by-product of incomplete combustion occurring in fossil fuel, biofuel and biomass burning. The black carbon (BC) content of the combustion particles is strongly absorbing at visible and infrared wavelengths, and is therefore an important contributor to the direct radiative forcing of the climate by atmospheric aerosols (Forster et al., 2007; Ramanathan and Carmichael, 2009). The current estimates of global radiative forcing from fossil fuel and biomass burning are positive $\left(\sim 0.4 \mathrm{~W} \mathrm{~m}^{-2}\right)$ and are comparable to the contribution of methane, the second most important greenhouse gas (Forster et al., 2007). The short lifetime of BC in the atmosphere (e.g. Schulz et al., 2006) and its predominantly anthropogenic sources (Ito and Penner, 2005; Stier et al., 2006) make it attractive for shortterm reduction strategies to reduce future warming of the climate (Jacobson, 2002; Bond and Sun, 2005; Bond, 2007; Grieshop et al., 2009; Rypdal et al., 2009).

However, carbonaceous combustion particles can also contain water-soluble material and therefore act as cloud condensation nuclei (CCN) (Zuberi et al., 2005), the number concentration of which governs the magnitude of the aerosol indirect radiative forcing on climate. Although BC 
particles are hydrophobic and are therefore poor $\mathrm{CCN}$, they are often co-emitted with hydrophilic particulate organic matter (POM) and can become internally mixed with this species. BC particles also become increasingly hydrophilic after emission, through condensation of sulfate, nitrate and secondary organic aerosol (SOA) onto the particle surfaces, referred to as particle "ageing" (e.g. Shiraiwa et al., 2007; Moffet and Prather, 2009; Wang et al., 2010; Cheng et al., 2012). The degree of mixing, or "mixing state", of atmospheric BC particles with these hydrophilic aerosol components not only influences their CCN activity (e.g. Rose et al., 2011), but also affects their radiative properties (e.g. Cheng et al., 2006) and is therefore important for assessing the direct radiative forcing of carbonaceous aerosol (Jacobson, 2001; Bond et al., 2006).

Global model studies show that carbonaceous combustion particles composed of BC and POM could make substantial contributions to global CCN concentrations (Pierce et al., 2007; Chen et al., 2010; Spracklen et al., 2011) and influence cloud properties (Bauer et al., 2010; Jacobson, 2010; Koch et al., 2011; Spracklen et al., 2011). Pierce et al. (2007) showed that carbonaceous aerosol increases global CCN concentrations at $0.2 \%$ supersaturation $(\mathrm{CCN}(0.2 \%))$ by $40-90 \%$, while Spracklen et al. (2011) used a global model and observations of $\mathrm{CCN}$ to show that carbonaceous aerosol accounts for over $50 \%$ of surface $\operatorname{CCN}(0.2 \%)$, and up to $80 \%$ over polluted continental regions. However, there are large uncertainties associated with the emission size distribution of primary carbonaceous particles in models leading to uncertainties in predicted CCN concentrations (Pierce et al., 2007; Pierce and Adams, 2009; Spracklen et al., 2011) and estimates of climate forcing (Bauer et al., 2010; Spracklen et al., 2011). Spracklen et al. (2011) find the global mean top-ofatmosphere aerosol indirect effect due to carbonaceous combustion aerosol ranges from -0.34 to $-1.08 \mathrm{~W} \mathrm{~m}^{-2}$ depending on the assumed emission size of carbonaceous particles.

Model predictions of $\mathrm{BC}$ mass concentrations from a wide range of aerosol and climate models (including models from the Aerosol Intercomparison Project; AeroCom) have been extensively evaluated against various atmospheric BC measurements (Schaap et al., 2004; Koch et al., 2009; Vignati et al., 2010; Schwarz et al., 2010b; Gilardoni et al., 2011). In addition, the key uncertainties associated with global modelling of atmospheric BC mass concentrations have been identified and investigated by Vignati et al. (2010) and recommendations made for comparing modelled and measured carbonaceous aerosol mass concentrations (Vignati et al., 2010; Gilardoni et al., 2011). However, much less is known about the size and number concentrations of carbonaceous aerosol particles, which are critical quantities for $\mathrm{CCN}$ and indirect forcing. More importantly, the contribution of carbonaceous aerosol to global and regional $\mathrm{CCN}$ concentrations, as quantified by Pierce et al. (2007) and Spracklen et al. (2011), has not been compared to observations of the BC itself. This is largely due to a lack of measurements of the number concentrations of atmospheric carbonaceous particles since measurements of atmospheric BC are almost entirely mass-based.

An important limitation for the absorption simulated by global and regional aerosol models is the requirement to make assumptions about the size distribution and mixing state for emitted BC at the sub-grid scale. The majority of global models (whether they simulate only aerosol mass or the full particle size distribution) assume that the $\mathrm{BC}$ and POM components are co-emitted as internally mixed particles, commonly referred to in global model studies as black carbon-organic carbon (BC/OC) particles. Some limited information is available very close to emission sources to suggest that a uniform $\mathrm{BC} / \mathrm{OC}$ mixture across the emitted size distribution (i.e. at particle sizes below $\sim 100 \mathrm{~nm}$ ) is not realistic (e.g. Kittelson et al., 2000, 2006; Baltensperger et al., 2002; Casati et al., 2007). However, since models are typically only evaluated against BC and OC mass concentrations, any information that might exist about the mixing state of different size particles is not included in the models. But the distribution of the $\mathrm{BC}$ component across the particle size distribution is very important since it determines the light absorption properties of the aerosol. For example, whether a few particles contain most of the BC or whether it is distributed across many particles gives substantially different aerosol optical properties.

Riemer et al. (2009) have developed a box model that explicitly resolves the size and composition of individual particles to simulate the evolution of the mixing state of BCcontaining particles (Riemer et al., 2010) and the associated optical and CCN activation properties (Zaveri et al., 2010) in an idealised urban plume. Zaveri et al. (2010) found that the assumption of internally mixed particles within model size bins can lead to an overprediction of $\mathrm{CCN}$ concentrations and $\mathrm{BC}$ absorption when compared to the particle-resolved results. However, the representation of the aerosol particles in the particle-resolved model has not been evaluated against size or composition measurements. Aquila et al. (2011) have developed and implemented a sub-model that tracks mass and number concentrations of $\mathrm{BC}$ particles in their different mixing states in a global atmospheric chemistry model. Their model performs reasonably well against measurements of total aerosol number concentrations and size distribution, but such particle-resolved models have yet to be evaluated against measurements of $\mathrm{BC}$ properties.

In recent years, advanced observation techniques using laser-induced incandescence have been developed (the Single Particle Soot Photometer; SP2), which allow simultaneous size-resolved measurements of the mass and number concentrations of the refractory and strongly light-absorbing component of combustion-generated carbonaceous aerosol (Stephens et al., 2003; Baumgardner et al., 2004; Schwarz et al., 2006). These measurements therefore enable the size distribution of the BC component to be separated from that of the total particle distribution. In this study we use 


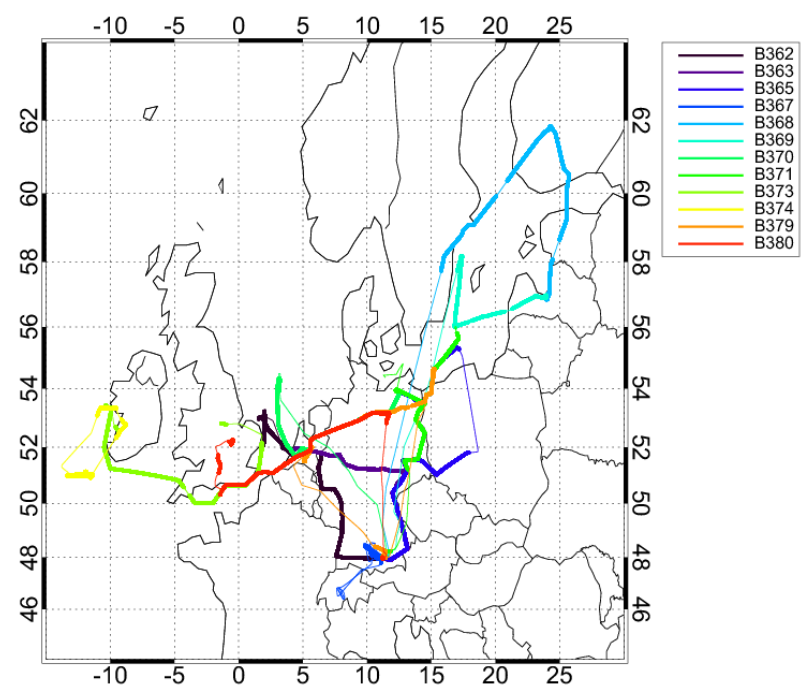

Fig. 1. Map of flight tracks performed by the FAAM BAe-146 research aircraft during the EUCAARI-LONGREX field campaign in May 2008. The flights shown are those with simultaneous SP2 and PCASP measurements available. Sections of the FAAM aircraft flight tracks that are below $3 \mathrm{~km}$ a.s.l. are shown in bold.

measurements from the SP2 instrument over Europe to evaluate model predictions of the physical properties of $\mathrm{BC}$. By comparing the number size distribution of $\mathrm{BC}$ particles with the total particle number size distribution, we are also able to quantify the modelled and measured number fractions of BC particles, thereby quantifying the contribution of carbonaceous aerosol to the number of particles at sizes relevant for $\mathrm{CCN}$.

\section{Observations}

We use observations from the LONG Range EXperiment (LONGREX), an intensive field campaign that took place between 6 and 24 May 2008 as part of the European Integrated Project on Aerosol Cloud Climate Air Quality Interactions (EUCAARI; Kulmala et al., 2009, 2011). Two research aircraft were operated during LONGREX: the DLR (Deutsches Zentrum für Luft- und Raumfahrt) Falcon 20-E5 aircraft and the BAe-146-301 large atmospheric research aircraft operated by the UK Facility for Airborne Atmospheric Measurements (FAAM). Here we use observations made on-board the FAAM aircraft, which mainly sampled in the boundary layer. The flight tracks of the FAAM aircraft performed during LONGREX are shown in Fig. 1.

The meteorological conditions of the LONGREX field campaign were characterised by two fairly distinct periods, which are described in detail by Hamburger et al. (2011). In the first half of the campaign (up to 15 May), the weather was dominated by a stable anticyclonic blocking event over Central Europe, with its core located over the northern Germany and Denmark. During this event the lack of cloud cover and precipitation led to an accumulation of pollutants inside the boundary layer within the core region of the high pressure system (Hamburger et al., 2011). Strong negative gradients in particle and $\mathrm{BC}$ mass concentrations were observed in aircraft vertical profiles between the well-mixed boundary layer and the relatively clean middle troposphere (McMeeking et al., 2010; Hamburger et al., 2011). During the second half of the campaign (16 May onwards), the anticyclone dissipated and the weather was dominated by westerly flow and passage of frontal systems over Central Europe. The majority of flights of the FAAM aircraft were performed during the first half of May 2008 (flights B362-B374 in Fig. 1).

The physical properties of the refractory and strongly light-absorbing component of carbonaceous aerosol were measured during LONGREX using the SP2 instrument (DMT Inc., Boulder, Colorado, USA). The term for the component detected by the SP2 is "refractory black carbon" (rBC) (e.g. Schwarz et al., 2010a; McMeeking et al., 2010), which has evolved from the terms "elemental carbon" (Gao et al., 2007) or "black carbon" (e.g. Schwarz et al., 2006) to more clearly define the material that is measured. The SP2 relies on laser-induced incandescence (Stephens et al., 2003) to quantify the mass of $\mathrm{rBC}$ in individual particles, which can be integrated to obtain mass and number concentrations for ambient $\mathrm{rBC}$ at high temporal resolution.

The boiling point temperature of atmospheric BC is sufficiently high so that when it absorbs the laser energy it incandescences with an intensity that is proportional to the mass (e.g. Schwarz et al., 2006). For particles consisting of internally mixed $\mathrm{BC}$ and non- $\mathrm{BC}$ material, the non-BC material will be vaporised at a lower temperature before the $\mathrm{BC}$ incandesces; thus the SP2 measures the mass size distribution of the rBC particle "cores". Here, the measured diameter is referred to as the $\mathrm{BC}$ core diameter, $D_{\mathrm{BC}}$, while the diameter of the internally mixed particles ( $\mathrm{rBC}$ core + non-rBC coating) is referred to as the coated particle diameter, $D_{\mathrm{p}}$.

The SP2 in this study measured $\mathrm{rBC}$ over a calibrated volume equivalent diameter (VED) range of $D_{\mathrm{BC}}=55-400 \mathrm{~nm}$, assuming an $\mathrm{rBC}$ density of $1.8 \mathrm{~g} \mathrm{~cm}^{-3}$ (McMeeking et al., 2010). The number-detection efficiency of the SP2 at sea level pressure is reported by Schwarz et al. (2010a) to be close to unity for $D_{\mathrm{BC}} \gtrsim 90 \mathrm{~nm}$ VED. We therefore restrict our model-observation comparison to the $\mathrm{BC}$ number size distribution above $90 \mathrm{~nm}$ dry diameter. An uncertainty of $\sim 30 \%$ has been reported for the mass measurement of a single rBC particle, corresponding to a $\sim 10 \%$ uncertainty in the measured $D_{\mathrm{BC}}$ (Shiraiwa et al., 2008; Schwarz et al., 2008; McMeeking et al., 2010). The SP2 instrument is also able to provide sizing information for non-incandescing (non-rBC) particles in the size range $D_{\mathrm{p}}=150-600 \mathrm{~nm}$ and information on the mixing state of rBC (e.g. McMeeking et al., 2011a,b), but these measurements are not available for this campaign period. 
The fairly narrow measurement range of the SP2 instrument ( $\sim 90-400 \mathrm{~nm} B C$ diameter) is unlikely to represent the total ambient number and mass concentrations of BC. By fitting log-normal distributions to aircraft SP2 measurements, Schwarz et al. (2006) find the SP2 detects approximately $\sim 60 \%$ of the total ambient BC mass and $\sim 5 \%$ of the total ambient $\mathrm{BC}$ number over a mid-latitude region (between 88 $98^{\circ} \mathrm{W}$ and $29-38^{\circ} \mathrm{N}$ ). The SP2 instrument used in this study has been upgraded to increase the sensitivity to smaller BC particles. Hence the measurements represent a larger fraction of the total ambient BC mass $(\sim 80 \%$, using the same approach as Schwarz et al. (2006)) (McMeeking et al., 2010). But the fraction of the ambient BC number detected by the instrument is still likely to be relatively small.

SP2 measurements are available from 13 LONGREX research flights of the FAAM aircraft. McMeeking et al. (2010) report that a problem related to pressure-dependent flow control in the instrument resulted in unreliable measurements at altitudes above approximately $2 \mathrm{~km}$. We therefore restrict the analysis of these measurements to altitudes below $2.5 \mathrm{~km}$ a.s.l. A more detailed description of the instrument and measurements used in this study can be found in McMeeking et al. (2010).

Measurements of the total particle size distribution were obtained using a wing-mounted Passive Cavity Aerosol Spectrometer Probe (PCASP)-100X (Particle Measurement Systems, Boulder, CO, USA). The PCASP instrument measured the particle size distribution in the dry diameter range of $\sim 0.1$ to $\sim 3.0 \mu \mathrm{m}$. An uncertainty of $\sim 30 \%$ is typically cited for PCASP volume measurements (e.g. Kleinman et al., 2012), corresponding to a $\sim 10 \%$ uncertainty in measured diameter. The PCASP measurements used in this study have not been corrected for the refractive indices of the ambient aerosol; the size distribution has been calibrated using the refractive index of the calibration diethylhexyl sebacate (DEHS) aerosol. PCASP number size distribution measurements are available for 12 of the FAAM aircraft LONGREX flights with SP2 measurements (shown in Fig. 1). In this study, all measured concentrations from the SP2 and PCASP instruments are reported at ambient conditions.

\section{Model description}

We use the global aerosol microphysics model, GLOMAP (e.g. Spracklen et al., 2005a,b; Korhonen et al., 2008; Merikanto et al., 2009; Reddington et al., 2011), which is an extension of the TOMCAT 3-D off-line Eulerian chemical transport model (Chipperfield, 2006). Large-scale atmospheric transport and meteorology is specified from 6-hourly ECMWF analyses. Turbulent mixing in the boundary layer and boundary layer height are calculated using the parameterisation of Holtslag and Boville (1993). The model has a horizontal resolution of $2.8^{\circ} \times 2.8^{\circ}$ and 31 vertical levels between the surface and $10 \mathrm{hPa}$. The vertical resolution in the boundary layer ranges from $\sim 60 \mathrm{~m}$ near the surface to $\sim 400 \mathrm{~m}$ at $\sim 2 \mathrm{~km}$ a.s.l.

GLOMAP simulates the evolution of size- and composition-resolved aerosols, including their interaction with trace gases and clouds. The aerosol size distribution is specified in terms of a two-moment sectional (bin) scheme with 20 bins spanning $\sim 3 \mathrm{~nm}$ to $\sim 10 \mu \mathrm{m}$ dry diameter. Microphysical processes in the model include nucleation, condensation of gas-phase species, coagulation, in-cloud and below-cloud aerosol scavenging and deposition, dry deposition, and cloud processing (sulfur chemistry on activated aerosol). Full details of the model microphysics scheme are given by Spracklen et al. (2005a) and Merikanto et al. (2009). The aerosol species in GLOMAP include sulfate, sea salt, and carbonaceous material, which is split into $\mathrm{BC}$ and POM.

Concentrations of oxidants $\mathrm{OH}, \mathrm{O}_{3}, \mathrm{NO}_{3}, \mathrm{H}_{2} \mathrm{O}_{2}$ and $\mathrm{HO}_{2}$ are specified using 6-hourly monthly-mean 3 -D gridded concentration fields from a TOMCAT simulation with detailed tropospheric chemistry (Arnold et al., 2005) and linearly interpolated onto the model timestep. Emissions of biogenic terpenes are based on Guenther et al. (1995). Emissions of sea salt are calculated using the scheme of Gong et al. (2003). Anthropogenic emissions of sulfur dioxide $\left(\mathrm{SO}_{2}\right.$; from industrial, power-plant, domestic, shipping, road transport, and off-road sources) are based on Cofala et al. (2005), and volcanic $\mathrm{SO}_{2}$ emissions are based on Andres and Kasgnoc (1998). To account for sub-grid production of sulfate particulates, we assume that $2.5 \%$ of $\mathrm{SO}_{2}$ from anthropogenic and volcanic sources is emitted as sulfuric acid particles. For the emission of sub-grid sulfate particles in the model, we assume the size distribution used by Stier et al. (2005), which is modified from the AeroCom recommendations for the year 2000 (Dentener et al., 2006). The emissions of carbonaceous aerosol used in the model are described in Sect. 3.1.

The formation of secondary sulfate particles in the free troposphere is simulated using the binary homogeneous $\mathrm{H}_{2} \mathrm{SO}_{4}-\mathrm{H}_{2} \mathrm{O}$ nucleation rates of Kulmala et al. (1998). In the boundary layer the model includes an empirical particle formation mechanism based on gaseous $\mathrm{H}_{2} \mathrm{SO}_{4}$ (e.g. Sihto et al., 2006; Kuang et al., 2008). In this mechanism the formation rate of sub- $3 \mathrm{~nm}$ molecular clusters $\left(J_{\text {nuc }}\right)$ is dependent on the gas-phase sulfuric acid concentration $\left(\left[\mathrm{H}_{2} \mathrm{SO}_{4}\right]\right)$ to the power of two $\left(J_{\text {nuc }}=K\left[\mathrm{H}_{2} \mathrm{SO}_{4}\right]^{2}, K=2 \times 10^{-12} \mathrm{~cm}^{3} \mathrm{~s}^{-1}\right)$.

A simple scheme for the formation of SOA is included in the model. This process involves the reaction of biogenic monoterpenes with $\mathrm{O}_{3}, \mathrm{OH}$ and $\mathrm{NO}_{3}$ to form a gasphase oxidation product with a constant mass yield of $14.3 \%$ (Spracklen et al., 2006). The reactivity of the gas-phase monoterpenes is assumed to be equal to that of $\alpha$-pinene. The first stage oxidation product can form SOA by condensing with zero vapour pressure onto all pre-existing particles (Spracklen et al., 2006, 2008) and is then treated as POM. 


\subsection{Carbonaceous aerosol in GLOMAP}

There is considerable ambiguity surrounding the definition and nomenclature of the strongly light-absorbing component of atmospheric carbonaceous aerosol produced by combustion sources, particularly in the context of aerosol and climate modelling (e.g. Bond et al., 2004; Bond and Bergstrom, 2006; Andreae and Gelencsér, 2006; Vignati et al., 2010). The terms "elemental carbon" (EC) and "black carbon" (BC) are often used interchangeably to describe this component. The fraction of carbonaceous aerosol in an organic form is referred to as "organic carbon" (OC) and is usually given zero absorption in models, although strictly speaking OC is partly absorbing (Bond et al., 2004).

The definitions of EC and BC have been discussed in detail in the literature (see e.g. Bond and Bergstrom, 2006; Andreae and Gelencsér, 2006), but in general their definitions are based on the measurement technique (thermo-optical or optical respectively) used to detect the particles. The differences between measurements of EC and BC in different environments have been quantified in several instrument intercomparison studies (e.g. ten Brink et al., 2004; Jeong et al., 2004; Hitzenberger et al., 2006; Bae et al., 2007; Ram et al., 2010). In general there is a high correlation between the measured mass concentrations of EC and BC (e.g. ten Brink et al., 2004; Jeong et al., 2004; Bae et al., 2007), but the differences in the absolute mass concentrations are highly variable. For example, Ram et al. (2010) found the BC mass concentration to be $\sim 20 \%$ higher than that of EC, whereas ten Brink et al. (2004) and Jeong et al. (2004) found a difference of up to a factor of 3 between measured BC and EC mass concentrations. It is important to note that, in the latter two measurement studies, large differences were also found between BC values obtained with the various optical methods, and ten Brink et al. (2004) found EC concentrations differed by up to a factor of $\sim 4$ between methods. The type of modelled carbonaceous aerosol will therefore depend on the measurements used to compile the model emission inventory.

In GLOMAP, emissions of carbonaceous combustion aerosol are based on AeroCom-prescribed emission data sets for the year 2000 (Dentener et al., 2006). The AeroCom inventory includes emissions of primary carbonaceous aerosol from anthropogenic (fossil fuel and biofuel) sources based on Bond et al. (2004) and from biomass burning following van der Werf et al. (2003). The emission inventory developed by Bond et al. (2004) is reported by Vignati et al. (2010) to be predominantly based on measurements of the refractive behaviour of carbon (thermo-optical measurements) and thus is more representative of EC. However, since systematic uncertainties associated with the measurements are generally larger than the operational differences in the measurement techniques, Bond et al. (2004) treat measurements of EC as equal to BC, referring to the quantity as "BC". In addition, Koch et al. (2009) refer to both the modelled and measured quantities as "BC" in their evaluation of AeroCom models against SP2 mass concentration measurements. To be consistent with Bond et al. (2004) and Koch et al. (2009), we use the term "BC" here to describe the modelled quantity.

SP2 measurements of $\mathrm{rBC}$ mass concentrations have been shown by several studies to be comparable to measurements of both EC- and BC-type mass concentrations (e.g. Slowik et al., 2007; Cross et al., 2010; Kondo et al., 2011). Kondo et al. (2011) found that ambient rBC measured by the SP2 agreed with mass concentrations of EC measured by a common filter-based thermal-optical technique and $\mathrm{BC}$ measured by a filter-based photo-absorption technique within $10 \%$ on average. Therefore in this study, we treat $\mathrm{rBC}$ as equivalent to the modelled $\mathrm{BC}$ mass concentration, though we note that there are differences between the SP2 measurement technique and the methods used to obtain $\mathrm{BC}$ emissions used in the model. We also assume the modelled and SP2-measured number size distributions of $\mathrm{BC}$ cores are comparable, but note that uncertainties associated with this assumption are not well quantified. Henceforth we refer to the SP2-measured quantity as "BC" as in Schwarz et al. (2006) and Koch et al. (2009).

Further uncertainty associated with modelling carbonaceous (BC and $\mathrm{OC}$ ) aerosol is introduced when estimating the emitted particle number flux from a mass-based emission inventory like the one used here. To calculate a number-emissions flux based on the mass-emissions flux, size-resolving models assume a fixed log-normal size distribution at emission, with a specified number median diameter $(D)$ and distribution width (standard deviation, $\sigma$ ). Several studies have shown that the assumption of an effective emission size distribution is a major source of uncertainty in simulated particle number concentrations (Reddington et al., 2011), subsequently leading to uncertainties in predicted CCN concentrations (Pierce et al., 2007; Pierce and Adams, 2009; Spracklen et al., 2011) and estimates of climate forcing (Bauer et al., 2010; Spracklen et al., 2011).

The uncertainty in simulated primary carbonaceous particle number concentrations is accounted for in our study by showing two model runs with different assumptions for the size of emitted particles (see Table 2). We refer to these two model runs as "BCOC_lg" for the large carbonaceous particles as assumed by Stier et al. (2005) and "BCOC_sm" for the small carbonaceous particles as recommended by AeroCom (Dentener et al., 2006). These two size assumptions imply very different emission fluxes of carbonaceous particles for the same mass. The differences in the log-normal size distribution parameters used by Stier et al. (2005) and Dentener et al. (2006) (Table 2) correspond to an overall factor $\sim 4.4$ difference in the number-emissions flux of fossil fuel carbonaceous particles. It is important to note, however, that the large difference in number-emissions flux given by these two size assumptions is more important for particle sizes $\lesssim 100 \mathrm{~nm}$ (dry diameter), which is the lower limit of the size range under examination in this study. 


\subsection{Set-up of particle distributions}

The model was set up with three separate particle distributions, each of which is a mixture of different chemical components. All three distributions are treated as hydrophilic and are wet scavenged. Each distribution tracks the mass concentration of each component and the total particle number concentration per size bin. The aerosol components in each distribution are summarised in Table 1. The distributions are as follows:

Distribution D1. receives only emitted carbonaceous (BC and $\mathrm{OC}$ ) particles. The $\mathrm{BC}$ and $\mathrm{OC}$ components are internally mixed (i.e. the components are assumed to mix instantaneously after emission); thus we refer to particles in this distribution as " $\mathrm{BC} / \mathrm{OC}$ " particles. Other aerosol components $\left(\mathrm{H}_{2} \mathrm{SO}_{4}\right.$ and $\left.\mathrm{SOA}\right)$ can condense onto and grow these particles, but no other primary or secondary (nucleated) particles enter this distribution. Particles are lost from this distribution through self-coagulation, coagulation with particles in D2 and D3, and through wet/dry deposition processes

Distribution D2. contains only particulate sulfate $\left(\mathrm{SO}_{4}\right)$, sea salt (SS), and POM. Particles enter this distribution through primary emissions of sea spray and from nucleation (including sub-grid nucleation of sulfate particles in plumes (Stevens et al., 2012)). Particles in this distribution can grow by irreversible condensation of the gas-phase $\mathrm{H}_{2} \mathrm{SO}_{4}$ and SOA components. As for D1, particles are lost from D2 through self-coagulation, coagulation with particles in $\mathrm{D} 1$ and $\mathrm{D} 3$, and through deposition processes

Distribution D3. contains mixed-component particles from coagulation between particles in D1 and particles in D2. Particles in D1 or $\mathrm{D} 2$ that coagulate with particles in $\mathrm{D} 3$ also enter this distribution. Thus all components exist in this distribution (BC, $\mathrm{POM}, \mathrm{SO}_{4}$, and SS). No particles are emitted into this distribution directly. The gasphase $\mathrm{H}_{2} \mathrm{SO}_{4}$ and SOA components can condense onto and grow particles in D3. Particles in this distribution are lost through selfcoagulation and deposition processes.

In the particle phase we associate SOA with OC, and the primary and secondary $\mathrm{OC}$ components are given the same properties. The OC component is assumed to exist in all particles as POM. The mass of POM from primary OC is set equal to $1.4 \times$ OC mass (Dentener et al., 2006).

The set-up of the model particle distributions described here differs from that used in Reddington et al. (2011) and all previous GLOMAP studies to enable the number concentration of $\mathrm{BC}$-containing particles to be tracked through coagulation processes. The distribution set-up used in previous GLOMAP-bin studies (e.g. Spracklen et al., 2008; Merikanto et al., 2009; Spracklen et al., 2010) assumed that mixed-composition particles resulting from coagulation between $\mathrm{BC} / \mathrm{OC}$ particles in $\mathrm{D} 1$ and $\mathrm{SO}_{4}$ or SS particles in $\mathrm{D} 2$ moved to the appropriate size bin in $\mathrm{D} 2$ and that $\mathrm{BC} / \mathrm{OC}$ particles in D1 moved to the equivalent size section of D2 once they accumulated a certain monolayer of water-soluble condensed material $\left(\mathrm{H}_{2} \mathrm{SO}_{4}\right.$ or SOA). However, this approach, while computationally faster, makes it impossible to track the number of BC "cores". In the set-up used here, particles
Table 1. Summary of the aerosol distributions and components simulated in GLOMAP for this study. We include the components of black carbon (BC), particulate organic matter (POM), sulfate $\left(\mathrm{SO}_{4}\right)$ and sea salt (SS). The aerosol particles in each distribution can grow via condensation of $\mathrm{H}_{2} \mathrm{SO}_{4}$ (which enters the $\mathrm{SO}_{4}$ component) and SOA (which enters the POM component).

\begin{tabular}{lll}
\hline Distribution & Components & Sources of particle number \\
\hline D1 & $\begin{array}{l}\mathrm{BC}, \mathrm{POM}, \\
\mathrm{SO}_{4}\end{array}$ & $\begin{array}{l}\text { Primary BC/OC particles from } \\
\text { fossil fuel, biofuel and biomass } \\
\text { burning. }\end{array}$ \\
$\mathrm{D} 2$ & $\begin{array}{l}\mathrm{SO}_{4}, \mathrm{SS}, \\
\mathrm{POM}\end{array}$ & $\begin{array}{l}\text { Primary (sub-grid) particulate } \\
\mathrm{SO}_{4} \text { from anthropogenic and } \\
\text { volcanic sources, secondary } \\
\text { (nucleated) } \mathrm{SO}_{4} \text { particles, and } \\
\text { primary SS particles. } \\
\end{array}$ \\
& & $\begin{array}{l}\text { Mixed component particles } \\
\text { from coagulation between } \\
\text { distributions D1 and D2. }\end{array}$ \\
D3 & $\mathrm{BO}_{4}, \mathrm{SS}$ &
\end{tabular}

Table 2. Summary of the log-normal size distribution parameters assumed in the model to calculate the number-emissions flux of BC/OC particles. The number median diameter $(D)$ and standard deviation $(\sigma)$ are specified for BC/OC particles emitted from fossil fuel (FF) and wildfire and biofuel (BF) sources. In this study we assume two scenarios for the size of $\mathrm{BC} / \mathrm{OC}$ particles at emission: small particles (BCOC_sm) and large particles (BCOC_lg), keeping the mass-emissions flux fixed.

\begin{tabular}{llll}
\hline $\begin{array}{l}\text { Simulation } \\
\text { name }\end{array}$ & $\begin{array}{l}\text { Number median } \\
\text { diameter }\end{array}$ & $\begin{array}{l}\text { Standard } \\
\text { deviation }\end{array}$ & Reference \\
\hline BCOC_lg & $\begin{array}{l}D_{\mathrm{FF}}=60 \mathrm{~nm} \\
D_{\mathrm{BF}}=150 \mathrm{~nm}\end{array}$ & $\sigma=1.59$ & $\begin{array}{l}\text { Stier et } \\
\text { al. (2005) }\end{array}$ \\
BCOC_sm & $\begin{array}{l}D_{\mathrm{FF}}=30 \mathrm{~nm} \\
D_{\mathrm{BF}}=80 \mathrm{~nm}\end{array}$ & $\sigma=1.8$ & $\begin{array}{l}\text { Dentener et } \\
\text { al. (2006) }\end{array}$ \\
\hline
\end{tabular}

enter D3 only through coagulation with $\mathrm{BC}$-containing particles; thus all particles in D3 contain a carbonaceous core, and the total number concentration of $\mathrm{BC}$ cores is the sum of particles in D1 and D3. All modelled concentrations are reported at ambient conditions.

\subsection{Description of model simulations}

The model aerosol fields were generated from an initially aerosol-free atmosphere initialised on 1 February 2008 and spun up for 90 days to produce a realistic aerosol distribution (Spracklen et al., 2005a). The model hourly-mean 3-D field over the European domain was linearly interpolated to the vertical and horizontal location of the aircraft. The two model experiments used in this study are summarised in Table 2 .

The model has previously been evaluated against measurements of total particle (Spracklen et al., 2010) and CCN concentrations (Spracklen et al., 2008; Korhonen et al., 2008; 

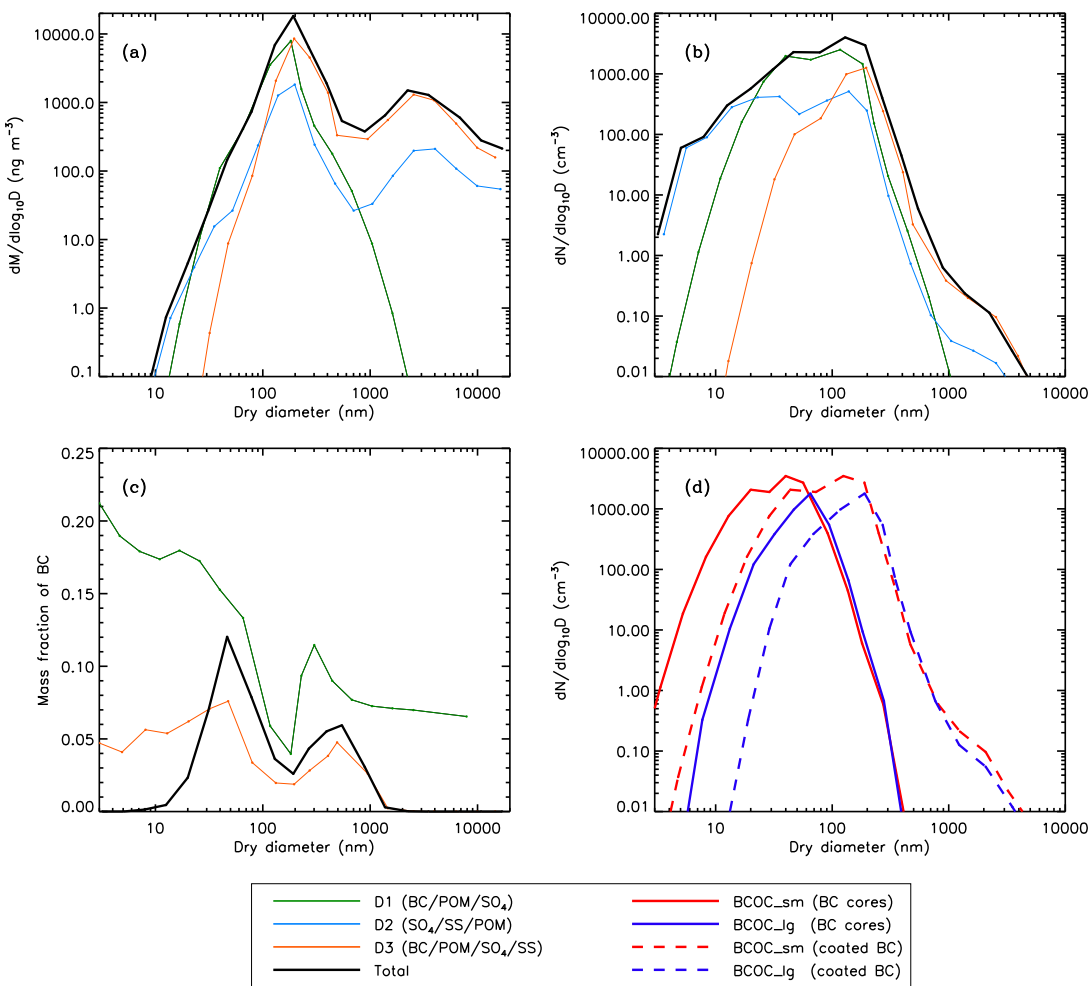

Fig. 2. Campaign-mean modelled (a) mass and (b) number size distributions for each aerosol distribution described in Table 1. Modelled size distributions were calculated along the flight tracks shown in Fig. 1 (for sections below $2.5 \mathrm{~km}$ a.s.1.) and averaged over all flights performed during EUCAARI-LONGREX. (c) Campaign-mean mass fraction of BC in each BC-containing distribution (D1 and D3) and in the total particle mass distribution (D1 + D2 + D3). In (a), (b), and (c) model results are shown for experiment BCOC_sm. (d) Campaign-mean number size distributions of coated BC particles and BC cores for model experiments BCOC_sm and BCOC_lg. The two model experiments are described in Table 2. The coated BC particle distribution is treated as the sum of the BC-containing aerosol distributions in (b) (i.e. $\mathrm{D} 1+\mathrm{D} 3)$. The size distribution of BC cores is calculated as described in Sect. 4.1.

Spracklen et al., 2011), as well as observations of the total and non-volatile particle number size distributions made during LONGREX (Reddington et al., 2011). For the campaign period the model reproduces surface observations of the total number size distribution across Europe, particularly at particle sizes relevant for CCN (Reddington et al., 2011). Evaluation of the modelled BC/OC particle number concentration against DLR Falcon aircraft measurements of non-volatile particles shows fairly good agreement (campaign-mean bias of $\sim-30 \%$ ) if we assume a small emission size for primary carbonaceous particles (experiment BCOC_sm). Here, we evaluate GLOMAP against observations of the BC particle size distribution for the first time.

\section{Results and discussion}

\subsection{The model BC size distribution}

In the model the size distribution of BC-containing particles ( $\mathrm{BC}$ core + non-BC coating) is the sum of particle distributions D1 and D3 (see Sect. 3.2). In distributions D1 and D3, the BC-containing particles can grow through selfcoagulation (which increases the $\mathrm{BC}$ core size, $D_{\mathrm{BC}}$ ) and via condensation of $\mathrm{H}_{2} \mathrm{SO}_{4}$ and SOA (which increases the total particle size, $D_{\mathrm{p}}$ ). Heterogeneous coagulation between particles in D1 and D3 will act to increase both $D_{\mathrm{BC}}$ and $D_{\mathrm{p}}$, whereas heterogeneous coagulation either between particles in D1 and D2 or between particles in D2 and D3 will only increase $D_{\mathrm{p}}$. In all cases of coagulation between particles in different distributions, the resultant particle enters D3.

To compare the model with the observed $\mathrm{BC}$ core size distributions, we remove the non- $\mathrm{BC}$ material $\left(\mathrm{POM}, \mathrm{SO}_{4}\right.$ and $\mathrm{SS})$ that is coating the $\mathrm{BC}$ cores, and the diameters of the cores $\left(D_{\mathrm{BC}}\right)$ are then calculated assuming spherical particles of density $(\rho) 1.8 \mathrm{~g} \mathrm{~cm}^{-3}$ :

$D_{\mathrm{BC}}=2\left[\frac{3}{4 \pi \rho} \frac{M_{\mathrm{BC}}}{N}\right]^{\frac{1}{3}}$,

where $M_{\mathrm{BC}}$ is the total mass of $\mathrm{BC}$ and $N$ is the number concentration of $\mathrm{BC}$ cores. $D_{\mathrm{BC}}$ is calculated separately for $\mathrm{D} 1$ and $\mathrm{D} 3$, and a combined distribution is calculated for comparison with the SP2. 
BCOC_sm experiment

(a)

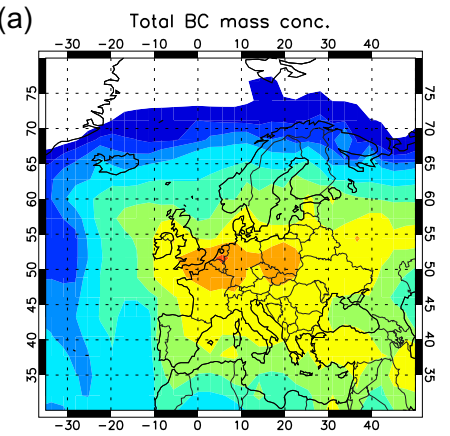

(c)

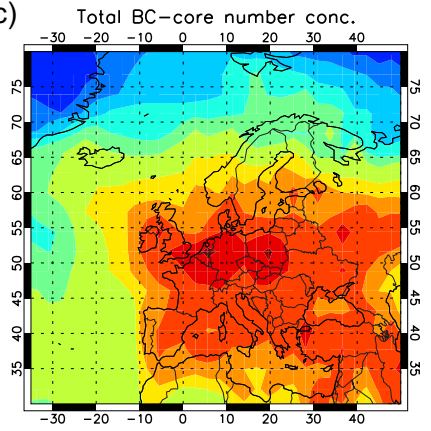

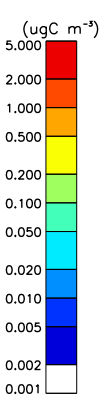

(b)
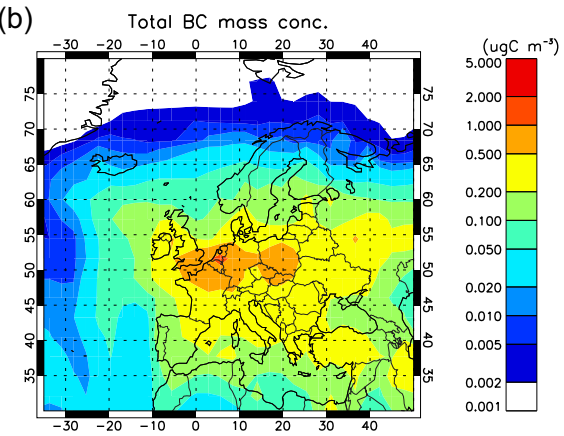

(d)

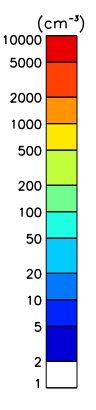

BCOC Ig experiment

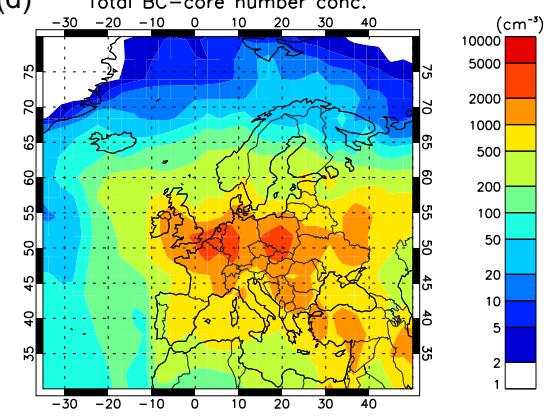

Fig. 3. Simulated campaign-mean (a) total BC mass concentration and (c) total BC-core number concentration at the surface over Europe. Concentrations simulated by experiment BCOC_sm are shown in (a) and (c); those simulated by experiment BCOC_lg are shown in (b) and (d). Concentrations were calculated by integrating over the total BC core size distribution (model distributions D1 + D3). To calculate the campaign mean, hourly mean modelled concentrations were averaged over the LONGREX campaign period (6-22 May 2008).

The campaign-mean modelled total particle mass and number size distributions are shown in Fig. $2 \mathrm{a}$ and $\mathrm{b}$ for the three aerosol distributions simulated in the model (D1, D2, and $\mathrm{D} 3$ ). Figure $2 \mathrm{c}$ shows the mass fraction of $\mathrm{BC}$ in distributions D1 and D3 and the $\mathrm{BC}$ mass fraction in the total particle mass distribution $(\mathrm{D} 1+\mathrm{D} 2+\mathrm{D} 3)$. The simulated number size distributions of $\mathrm{BC}$ cores and coated $\mathrm{BC}$ cores, averaged over the campaign period, are shown in Fig. 2 d. The modelled distribution of coated BC particles is shifted to larger sizes relative to the $\mathrm{BC}$ core size distribution, but the total number concentration is conserved. The tail of the coated $\mathrm{BC}$ particle distribution above $\sim 1$ micron disappears in the $\mathrm{BC}$ core distribution because internally mixed particles with $D_{\mathrm{p}}>1 \mu \mathrm{m}$ contain a relatively small mass fraction of BC (Fig. 2c). The number concentration of these BC cores is included in the $\mathrm{BC}$ core size distribution at much smaller sizes relative to the total particle size.

Figure 3 shows the campaign-mean total BC-core mass and number concentrations over Europe simulated by the two model experiments. For the LONGREX campaign period, the spatial distribution of simulated mass concentrations is consistent with the analysis of the observations by McMeeking et al. (2010), with peak mean BC mass concentrations simulated over north-west Europe. There is very little difference between the spatial distribution and magnitude of to- tal BC mass concentrations simulated by the two model experiments because the $\mathrm{BC}$ mass-emissions flux is kept fixed. However, the differences between the BC/OC particle sizes assumed at emission (Table 2) lead to substantial differences between the simulated number concentrations of $\mathrm{BC}$ cores. At the surface, the simulated campaign-mean total BC core number concentration is a factor $\sim 3.3$ higher in experiment BCOC_sm than in experiment BCOC_lg when averaged over the European domain.

For comparison with observations, the modelled BC-core mass and number size distributions were integrated between the upper and lower size limits of the SP2 measurement range, taking into account fractions of bins that span the SP2 limits. Previous studies comparing modelled BC mass concentrations with SP2 measurements have applied a scaling factor to account for BC mass that may lie outside the detection range of the instrument (e.g. Schwarz et al., 2006, 2010b; Koch et al., 2009). The scaling factor is calculated from the difference between the area under a log-normal fit and the SP2-measured BC mass concentration. However, it is only necessary to apply a scaling factor when evaluating bulk mass values. The GLOMAP model provides BC mass (and number) concentration as a function of size - allowing us to perform a direct comparison with SP2 measurements within the specific detection range. 

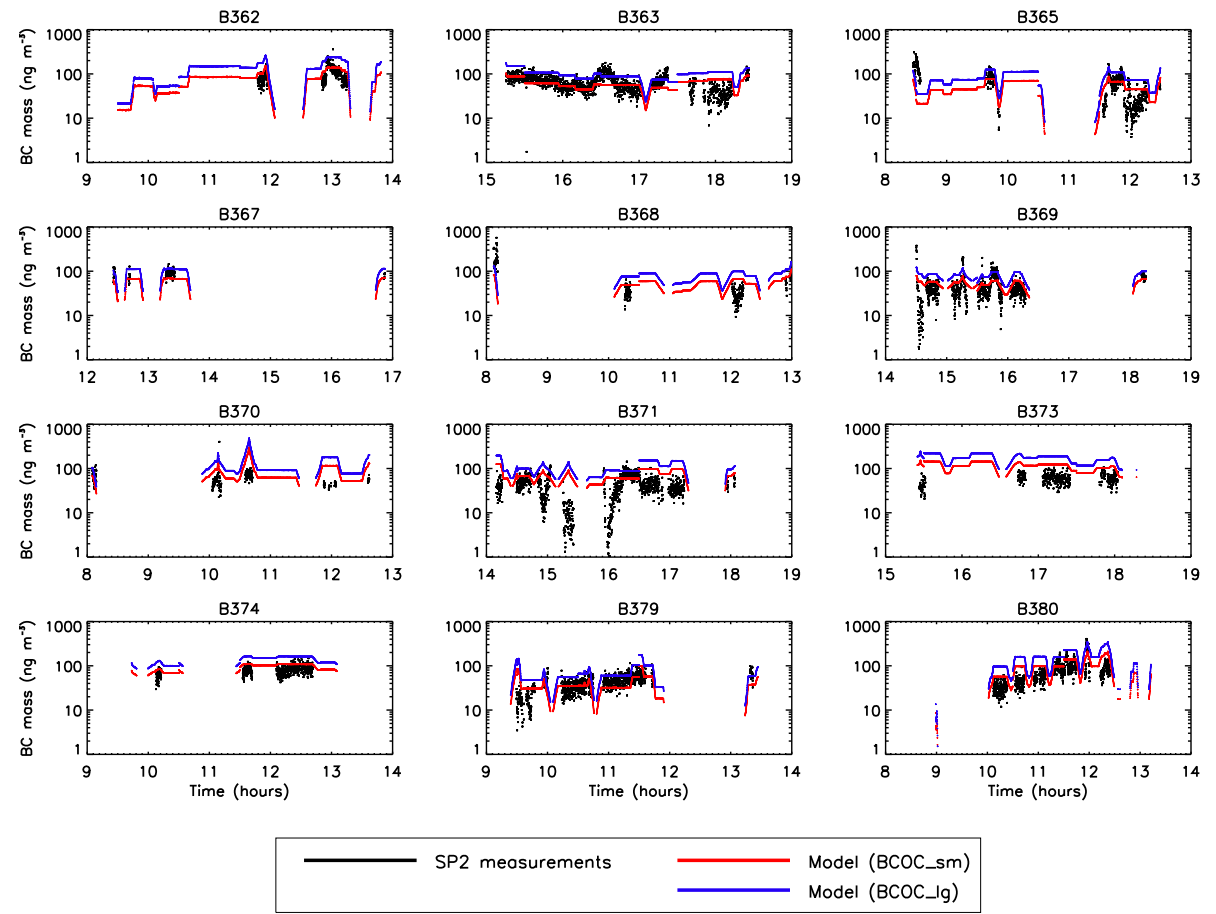

Fig. 4. Time series of modelled (colour) and observed (black) BC mass concentrations in the size range $D_{\mathrm{BC}}=90-400 \mathrm{~nm}$ for 12 EUCAARILONGREX flights of the FAAM aircraft. Concentrations are shown for altitudes below $2.5 \mathrm{~km}$. Observations of BC mass were made using the SP2 instrument (DMT Inc., Boulder, Colorado, USA). Model experiments, BCOC_sm and BCOC_lg, are described in Table 2.

\subsection{Evaluation of the modelled BC mass size distribution}

Figure 4 shows the modelled and observed time series of BC mass concentrations (at ambient conditions) in the dry diameter size range $\sim 90-400 \mathrm{~nm}$ for the FAAM aircraft flights shown in Fig. 1. BC concentrations are only shown for flight sections below $2.5 \mathrm{~km}$ (see Sect. 2). Model data corresponding to missing SP2 measurements were removed prior to analysis. Mean modelled and observed BC mass concentrations are given for each flight and for the whole campaign period in Table 3. The normalised mean bias (NMB), calculated between simulated $\left(S_{i}\right)$ and observed $\left(O_{i}\right)$ BC mass concentrations as $\operatorname{NMB}(\%)=100 \times \sum\left(S_{i}-O_{i}\right) / \sum O_{i}$, is also given in Table 3.

Mean observed BC mass concentrations in the SP2 size range for each flight range from $\sim 42$ to $\sim 101 \mathrm{ng} \mathrm{m}^{-3}$, with a campaign-mean concentration of $61 \mathrm{ng} \mathrm{m}^{-3}$. Simulated flight-mean $\mathrm{BC}$ mass concentrations range from 40 to $124 \mathrm{ng} \mathrm{m}^{-3}$ (campaign mean of $76 \mathrm{ng} \mathrm{m}^{-3}$ ) in the BCOC_sm model experiment and from 70 to $212 \mathrm{ng} \mathrm{m}^{-3}$ (campaign mean of $122 \mathrm{ng} \mathrm{m}^{-3}$ ) in the BCOC_lg experiment. The model predicts average $\mathrm{BC}$ mass concentrations for each flight within a factor of $\sim 2$ in experiment BCOC_sm $(\mathrm{NMB}=-27 \%$ to $103 \%)$ and within a factor of $\sim 3.1$ in experiment $\mathrm{BCOC} \_\mathrm{lg}(\mathrm{NMB}=20 \%$ to $212 \%)$.
Averaged over the whole campaign period, we find that the model captures the observed BC mass in the BCOC_sm experiment, with a small NMB of only $25 \%$, but a larger bias of $99 \%$ in the BCOC_lg experiment. However, both campaignmean modelled concentrations lie within the uncertainty associated with the carbonaceous emission inventory applied in the model, which is around a factor of 2 (Bond et al., 2004). The factor $\sim 2$ uncertainty reported by Bond et al. (2004) results from combined uncertainties in particulate matter emission factors, emission characterisation, and fuel use.

Figure 5 shows the longitudinal distribution of modelled and observed BC mass concentrations (in the SP2 size range) across Europe for the campaign period. The highest mean BC mass concentrations were observed between $5^{\circ} \mathrm{W}$ and $5^{\circ} \mathrm{E}$, with mean concentrations in each longitude bin generally increasing from east to west. The east-west gradient in observed BC mass concentrations was due to the lack of cloud cover and precipitation during the first half of the campaign, leading to an accumulation of pollution in the air masses as they moved west (Sect. 2; McMeeking et al., 2010; Hamburger et al., 2011). The model captures the east-west gradient in observed $\mathrm{BC}$ mass concentrations and captures the magnitude of the observed concentrations well (within $1 \sigma$ ) between $\sim 0-25^{\circ} \mathrm{E}$ in the BCOC_sm experiment. However, mean concentrations observed between $0-10^{\circ} \mathrm{W}$ are overpredicted by both model experiments. 
Table 3. Mean modelled and observed BC mass concentrations for 12 FAAM aircraft flights performed during EUCAARI-LONGREX (6-24 May 2008) and for the whole campaign period. The mean values were only calculated for flight sections below $2.5 \mathrm{~km}$ a.s.1. The normalised mean bias (NMB) between simulated and observed mass concentrations was calculated as described in the text (see Sect. 4.2). The modelled BC mass was integrated over the same size range measured by the SP2 $\left(D_{\mathrm{BC}}=90-400 \mathrm{~nm}\right)$. The two model experiments are described in Table 2 .

\begin{tabular}{llccccr}
\hline & & & \multicolumn{3}{c}{ Modelled } \\
& & Observed & BCOC_sm & BCOC_lg \\
\hline Date & Flight & $\begin{array}{c}\text { Mean } \\
\left(\mathrm{ng} \mathrm{m}^{-3}\right)\end{array}$ & $\begin{array}{c}\text { Mean } \\
\left(\mathrm{ng} \mathrm{m}^{-3}\right)\end{array}$ & NMB & $\begin{array}{c}\text { Mean } \\
\left(\mathrm{ng} \mathrm{m}^{-3}\right)\end{array}$ & NMB \\
\hline $06 / 05 / 2008$ & B362 & 101 & 124 & $22 \%$ & 212 & $110 \%$ \\
$06 / 05 / 2008$ & B363 & 66 & 62 & $-6 \%$ & 101 & $53 \%$ \\
$08 / 05 / 2008$ & B365 & 62 & 55 & $-12 \%$ & 89 & $42 \%$ \\
$09 / 05 / 2008$ & B367 & 91 & 66 & $-27 \%$ & 109 & $20 \%$ \\
$10 / 05 / 2008$ & B368 & 66 & 61 & $-8 \%$ & 92 & $39 \%$ \\
$10 / 05 / 2008$ & B369 & 48 & 56 & $17 \%$ & 85 & $78 \%$ \\
$12 / 05 / 2008$ & B370 & 60 & 121 & $101 \%$ & 188 & $212 \%$ \\
$12 / 05 / 2008$ & B371 & 43 & 77 & $80 \%$ & 116 & $172 \%$ \\
$13 / 05 / 2008$ & B373 & 59 & 119 & $103 \%$ & 182 & $210 \%$ \\
$14 / 05 / 2008$ & B374 & 81 & 106 & $30 \%$ & 158 & $94 \%$ \\
$21 / 05 / 2008$ & B379 & 42 & 40 & $-4 \%$ & 70 & $68 \%$ \\
$22 / 05 / 2008$ & B380 & 78 & 112 & $44 \%$ & 183 & $136 \%$ \\
\hline $06-22 / 05 / 2008$ & Campaign & 61 & 76 & $25 \%$ & 122 & $99 \%$ \\
\hline
\end{tabular}

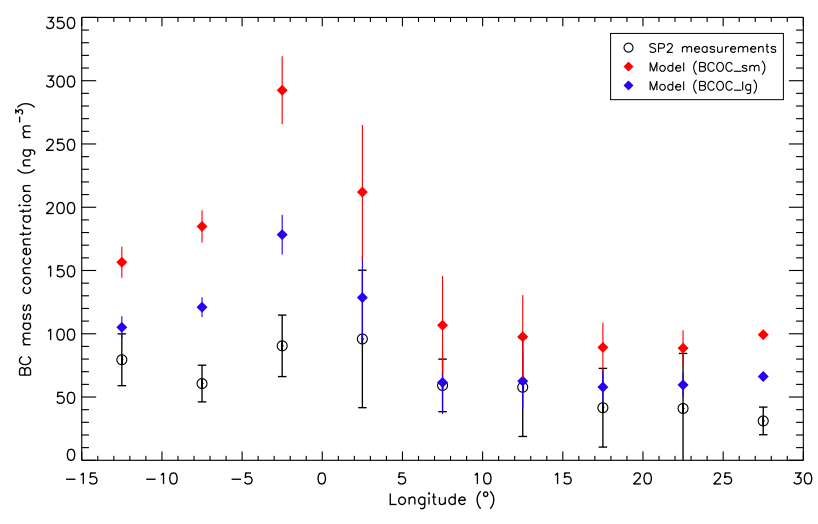

Fig. 5. The longitudinal distribution of modelled and observed $\mathrm{BC}$ mass concentrations in the size range $D_{\mathrm{BC}}=90-400 \mathrm{~nm}$ for the LONGREX campaign. The modelled and observed data points are mean values from 12 FAAM aircraft flights, divided into $5^{\circ}$ longitude bins. The error bars represent the standard deviation. Model experiments, BCOC_sm and BCOC_lg, are described in Table 2.

The vertical profiles of BC mass concentration averaged over the LONGREX campaign period are shown in Fig. 6a. Below $\sim 1.8 \mathrm{~km}$ altitude, modelled concentrations in the SP2 size range generally lie within $1 \sigma$ (experiment BCOC_sm) or $2 \sigma$ (experiment BCOC_lg) of the observations. Between $\sim 1.8$ and $\sim 2.5 \mathrm{~km}$ altitude, the model underpredicts the mean observed BC concentrations by a factor of $\sim 2.9-4.7$ (depending on the model experiment). This underprediction could be due to differences between modelled and observed boundary layer height or exchange of particles between the boundary layer and free troposphere. However, caution must be taken when comparing the modelled and observed profiles in regions where the number of data points is relatively low (total number of measurements, $n<100$ ), because the observations may be biased high, e.g. from a sub-grid-scale aerosol plume. Below $\sim 1.5 \mathrm{~km}$ altitude, where there is a high density of data points $\left(n>7 \times 10^{3}\right)$, the model captures the mean observed mass concentrations within a factor of 1.3 in experiment BCOC_sm and within a factor of 2.1 in experiment BCOC_lg. The overprediction of concentrations in experiment BCOC_lg is evident in Fig. 6a near the surface (below $\sim 500 \mathrm{~m}$ altitude).

Across the different flights, $\mathrm{BC}$ mass concentrations predicted by experiment BCOC_lg are higher by a factor of $\sim 1.5-1.8$ than concentrations predicted by experiment BCOC_sm, in the detection range of the SP2 (Figs. 4 and 6a). However, the total BC mass concentrations predicted by the two experiments are similar (within $\sim 6 \%$; see Fig. $3 a, b$ and the dashed lines in Fig. 6a). Thus, the differences within the SP2 size range are due to differences in the assumed size distributions of emitted carbonaceous particles (see Table 2), which results in a shift in the predicted BC mass size distributions, shown in Fig. 7.

The campaign-mean modelled size distribution of $\mathrm{BC}$ mass is shifted by a factor of $\sim 2.4-3.2$ (or by approximately $110-130 \mathrm{~nm}$ in diameter) to smaller sizes compared to the observations (Fig. 7). The modelled BC mass distribution also peaks at higher mass concentrations than the observations. Using a log-normal fit to the SP2 observations (as 

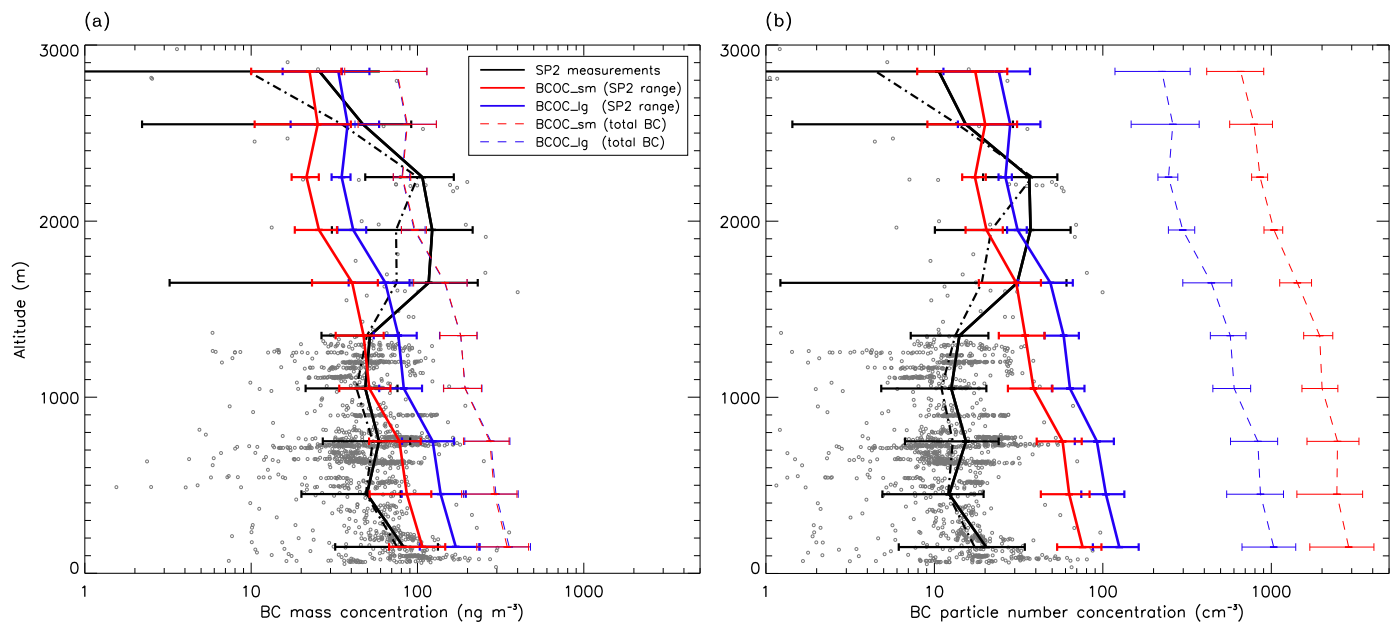

Fig. 6. Vertical profiles of modelled (colour) and observed (black) BC core (a) mass and (b) number concentrations. The profiles are an average of 12 FAAM aircraft flights performed during LONGREX (sectioned into $300 \mathrm{~m}$ altitude bins). The solid lines show mean modelled and observed concentrations in the detection range of the SP2 $\left(D_{\mathrm{BC}}=90-400 \mathrm{~nm}\right)$; the black dot-dashed lines show median observed concentrations. The dashed lines show mean total modelled BC concentrations (calculated by integrating over the whole $\mathrm{BC}$ core size distribution). The standard deviation is represented by the error bars. Individual $30 \mathrm{~s}$ averaged observation points are shown in grey. Model experiments, BCOC_sm and BCOC_lg, are described in Table 2. Modelled and observed concentrations are at ambient conditions.

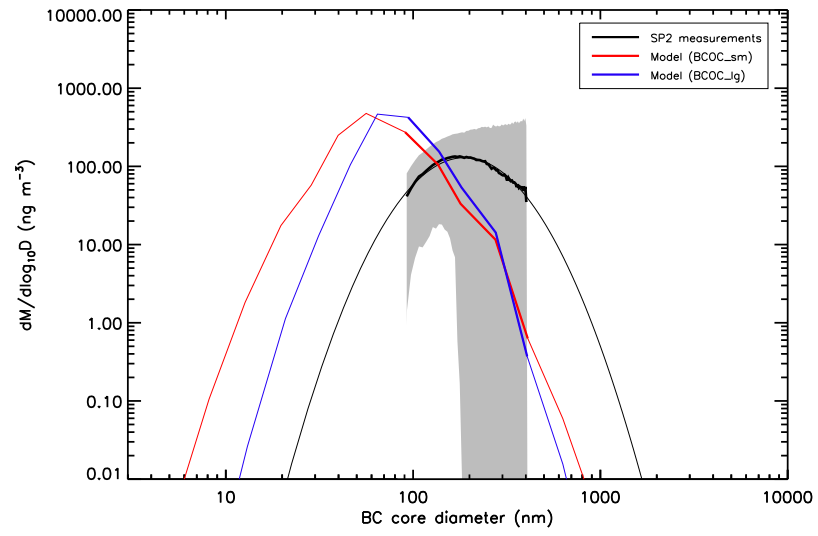

Fig. 7. Campaign-mean modelled (colour) and observed (black) BC mass size distributions. The modelled and observed size distributions of $\mathrm{BC}$ cores in the measurement range of the SP2 are shown by the bold, solid lines; a log-normal fit to the observed distribution is shown by the fine black line. The grey shading represents the standard deviation of the SP2 measurements.

shown in Fig. 7), McMeeking et al. (2010) find that a scaling factor of $\sim 1$ to 1.2 is necessary to account for missing $\mathrm{BC}$ mass outside the SP2 size range, i.e. suggesting that only $\sim 20 \%$ of $\mathrm{BC}$ mass lies beyond the detection limits of the SP2. If we compare the total modelled BC mass concentration with the SP2-measured mass concentration scaled by a factor of 1.2 , we find the model is biased high in both experiments (BCOC_sm, $\mathrm{NMB}=239 \%$; BCOC_lg, $\mathrm{NMB}=245 \%$ ).

Previous studies comparing total modelled BC mass concentrations, with SP2 measurements multiplied by a scaling factor, have also found a general model overestimation over both remote (Schwarz et al., 2010b) and continental (Koch et al., 2009) regions. Koch et al. (2009) find the average AeroCom model overpredicts the observed vertical profile of total $\mathrm{BC}$ mass concentration by a factor of 8 over the Americas. The bias between our modelled and observed total BC mass concentrations (NMB $\sim 240 \%$ ) lies well within the range in bias of the AeroCom model predictions (NMB $=-71 \%$ to $+670 \%$ ) presented by Koch et al. (2009).

The model overprediction of the total $\mathrm{BC}$ mass concentration lies outside the factor $\sim 2$ uncertainty of the carbonaceous particle emission inventory, which suggests the high model bias can only be partly explained by the uncertainty in the emissions. However, there may be additional uncertainties to consider regarding BC-measurement methods; Bond et al. (2004) combine measurements made using both thermo-optical and optical techniques, which introduces an additional uncertainty in the modelled quantity.

A further explanation for the high model bias could be that the log-normal fit to the observations (Fig. 7) may underestimate the total ambient $\mathrm{BC}$ mass concentrations. Although the $\mathrm{BC}$ mass size distribution predicted by the model is close to unimodal, there may be an additional mode in the ambient $\mathrm{BC}$ mass size distribution at sizes below the detection limit of the SP2, which is not represented by the log-normal fit. However, a mode in the $\mathrm{BC}$ mass distribution at sizes around $50 \mathrm{~nm}$ diameter would be unlikely away from source regions. 
Table 4. As for Table 3 but for modelled and observed number concentrations of BC cores, also in the size range $D_{\mathrm{BC}}=90-400 \mathrm{~nm}$.

\begin{tabular}{lcccccc}
\hline & & & \multicolumn{4}{c}{ Modelled } \\
& & Observed & BCOC_sm & BCOC_lg \\
\hline Date & Flight & $\begin{array}{c}\text { Mean } \\
\left(\mathrm{cm}^{-3}\right)\end{array}$ & $\begin{array}{c}\text { Mean } \\
\left(\mathrm{cm}^{-3}\right)\end{array}$ & NMB & $\begin{array}{c}\text { Mean } \\
\left(\mathrm{cm}^{-3}\right)\end{array}$ & NMB \\
\hline $06 / 05 / 2008$ & B362 & 28 & 77 & $175 \%$ & 150 & $433 \%$ \\
$06 / 05 / 2008$ & B363 & 17 & 43 & $152 \%$ & 73 & $330 \%$ \\
$08 / 05 / 2008$ & B365 & 18 & 43 & $132 \%$ & 67 & $261 \%$ \\
$09 / 05 / 2008$ & B367 & 27 & 47 & $72 \%$ & 78 & $190 \%$ \\
$10 / 05 / 2008$ & B368 & 18 & 48 & $166 \%$ & 83 & $357 \%$ \\
$10 / 05 / 2008$ & B369 & 12 & 47 & $286 \%$ & 79 & $552 \%$ \\
$12 / 05 / 2008$ & B370 & 15 & 87 & $484 \%$ & 130 & $773 \%$ \\
$12 / 05 / 2008$ & B371 & 11 & 60 & $473 \%$ & 96 & $809 \%$ \\
$13 / 05 / 2008$ & B373 & 12 & 85 & $627 \%$ & 126 & $978 \%$ \\
$14 / 05 / 2008$ & B374 & 17 & 77 & $362 \%$ & 117 & $600 \%$ \\
$21 / 05 / 2008$ & B379 & 11 & 31 & $177 \%$ & 56 & $391 \%$ \\
$22 / 05 / 2008$ & B380 & 22 & 78 & $257 \%$ & 122 & $460 \%$ \\
\hline $06-22 / 05 / 2008$ & Campaign & 16 & 56 & $248 \%$ & 91 & $466 \%$ \\
\hline
\end{tabular}

\subsection{Evaluation of the modelled BC particle number size distribution}

Modelled and observed BC particle number concentrations in the SP2 size range are given for each flight and for the whole campaign period in Table 4. Measured flight-mean number concentrations in the range of the SP2 lie between $\sim 11$ and $\sim 28 \mathrm{~cm}^{-3}$, with a campaign mean of $16 \mathrm{~cm}^{-3}$. Modelled flight-mean number concentrations range from 31 to $87 \mathrm{~cm}^{-3}$ in experiment BCOC_sm and from 56 to $150 \mathrm{~cm}^{-3}$ in experiment BCOC_lg, overpredicting the observations by a factor of $\sim 1.7-10.8$. Over the campaign period, the model is clearly biased high in the measurement range of the SP2 (see Table 4); the NMB between modelled and observed flight-mean concentrations is $248 \%$ in BCOC_sm (campaign mean $56 \mathrm{~cm}^{-3}$ ) and $466 \%$ in BCOC_lg (campaign mean $91 \mathrm{~cm}^{-3}$ ).

The campaign-mean vertical profiles of modelled and observed BC particle number concentrations are shown in Fig. 6b. The model overprediction is evident below an altitude of $\sim 1.5 \mathrm{~km}$, where the ambient BC particle number concentration will be strongly dependent on the regional primary carbonaceous emissions. Above this altitude the standard deviation of the model and the observations generally overlap. However, as mentioned in Sect 4.2, the lack of measurements above $\sim 1.8 \mathrm{~km}$ altitude could lead to biases in the observations.

Campaign-mean number size distributions of modelled and observed BC cores are compared in Fig. 8 (solid lines). As discussed in Sect. 4.1, the BC core size distribution is shifted to smaller sizes relative to the total particle size distribution (dashed lines), which represents the size of the whole (BC-containing and non-BC) particles. The large pos- itive bias of the model is caused by an overprediction of $\mathrm{BC}$ particle concentrations between $90 \mathrm{~nm}$ and $\sim 130 \mathrm{~nm}$ BC diameter. The agreement improves at larger sizes where the model is within the standard deviation of the SP2 observations. However, in general the modelled BC number size distribution decreases too steeply in the measurement range of the SP2 relative to the observations, and lies outside of the $10 \%$ uncertainty range associated with the measured diameter (not shown in Fig. 8).

The number median sizes of $\mathrm{BC}$ cores in the model and observations also differ. The campaign-mean modelled BC particle size distribution peaks at diameters of $\sim 35 \mathrm{~nm}$ and $\sim 60 \mathrm{~nm}$ in the BCOC_sm and BCOC_lg experiments, respectively. By fitting a log-normal distribution to the SP2 measurements (see Fig. 8), we estimate the observed BC number size distribution to peak at $D_{\mathrm{BC}} \sim 100 \mathrm{~nm}$ and at a lower number concentration than the model. Schwarz et al. (2006) fitted a log-normal distribution to their SP2 number distribution measurements and found the peak concentration to be around $60 \mathrm{~nm} \mathrm{VED}$, for measurements below $5 \mathrm{~km}$, which is in better agreement with our model results. However, the measurements of Schwarz et al. (2006) were conducted over North America (between $88-98^{\circ} \mathrm{W}$ and $29-38^{\circ} \mathrm{N}$ ) so may not be comparable to European observations and model data. In addition, the instrument used in this chapter had been upgraded to have an increased sensitivity to smaller BC particles so as to provide a more reliable measurement of the peak diameter of the ambient $\mathrm{BC}$ number size distribution.

There are several possible explanations for the shift in the modelled BC number size distribution to smaller sizes than observed and for the high bias in predicted BC particle number concentrations. Firstly, the size distribution of the emitted $\mathrm{BC}$ component of the carbonaceous aerosol could be larger 


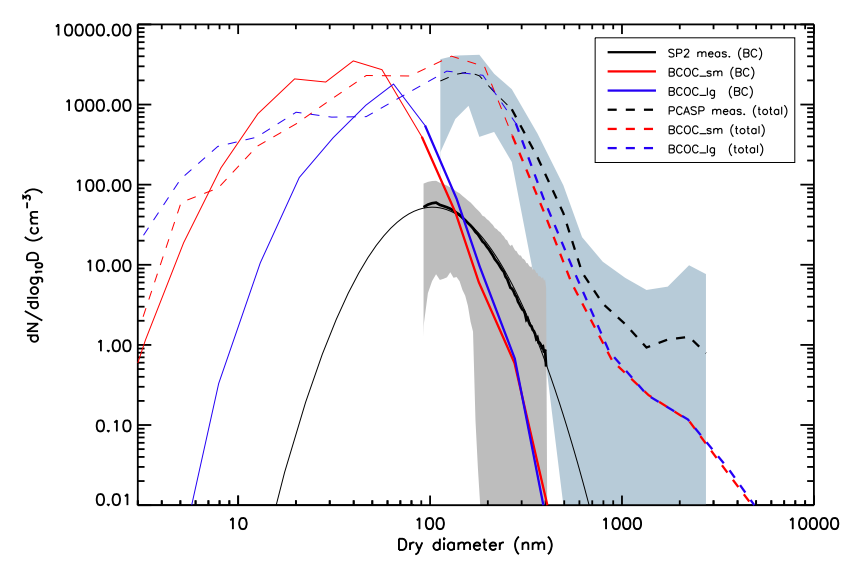

Fig. 8. Campaign-mean modelled (colour) and observed (black) number size distributions of BC cores (solid lines) and total particles (dashed lines). The sections of the size distributions within the SP2 measurement range $\left(D_{\mathrm{BC}}=90-400 \mathrm{~nm}\right)$ and mean coatedparticle size range defined by the model $\left(D_{\mathrm{p}} \sim 260-4500 \mathrm{~nm}\right)$ are shown in bold. A log-normal fit to the observed BC core size distribution is shown by the fine black line. The grey and blue shading represent the standard deviation of the SP2 and PCASP measurements, respectively.

than assumed in the model. Increasing the number median diameter of the emitted carbonaceous size distribution, keeping the emitted mass concentration fixed, would shift the BC core size distribution to larger sizes and reduce the peak number concentration. The assumption of an effective emission size distribution for primary BC/OC particles is highly uncertain and assumptions vary widely between models (e.g. Textor et al., 2006). Although we have tested two assumptions for the $\mathrm{BC} / \mathrm{OC}$ emission size distribution (BCOC_sm and $\mathrm{BCOC}_{-} \mathrm{lg}$ ), these two experiments are unlikely to represent the full uncertainty range in the parameterisation of carbonaceous particle emissions in global models (see e.g. the ranges applied in Lee et al. (2013)).

Secondly, as discussed for the measured BC mass size distribution in the previous section, there could be additional modes in the $\mathrm{BC}$ number size distribution at sizes below the detection limit of the SP2. A mode below $\sim 90 \mathrm{~nm}$ in the BC particle size distribution is more likely in terms of number than in terms of mass. Figure 8 shows that the large mode in the modelled $\mathrm{BC}$ core size distribution is mostly below the size range detectable by the SP2 (in both model experiments). If there is an ambient $\mathrm{BC}$ size mode present below $\sim 90 \mathrm{~nm}$, it could explain much of the model discrepancy in terms of number, since a small shift in the size distribution would account for the model-observation differences. However, the greatest model-observation difference in the $\mathrm{BC}$ mass distribution occurs at $D_{\mathrm{BC}}>200 \mathrm{~nm}$.

Finally, there are uncertainties associated with the measurements that may partly explain the high model bias. The detection efficiency is shown by Schwarz et al. (2010a) (Fig. 11) to decrease as a function of coating mass for BC core diameters below $\sim 125 \mathrm{~nm}$ VED. Essentially, BC cores at the lower limit of the $\mathrm{BC}$ response range of the SP2 can be missed if they have coatings thick enough to quench the heating that occurs when the particle is illuminated by the laser. For a BC core mass of between $\sim 0.8$ and $2 \mathrm{fg}$ (corresponding to $D_{\mathrm{BC}} \sim 90 \mathrm{~nm}-125 \mathrm{~nm}$ ), the detection efficiency was found to decrease to $\lesssim 50 \%$ if the coating mass exceeded $\sim 9 \mathrm{fg}$ (Schwarz et al., 2010a). In the model, all BC-containing particles with a BC core size within the SP2 range are counted, even if they have thick coatings. Figure 9 shows the modelled $\mathrm{BC}$ and coating mass per particle in distributions D1 and D3. At BC core diameters of $\sim 90-100 \mathrm{~nm}$, the mean coating mass per particle in D1 $(\sim 8-10 \mathrm{fg})$ is close to the limit observed by Schwarz et al. (2010a). However, in D3 the coating mass per particle is larger ( $\gtrsim 20 \mathrm{fg}$ at $\sim 90-100 \mathrm{~nm}$ ), suggesting a fraction of BC cores between $\sim 90-100 \mathrm{~nm}$ may be undercounted by the SP2. Removing the contribution of D3 to the modelled $\mathrm{BC}$ core number concentration reduces the campaign mean by $\sim 41-49 \%$, but the model remains biased high $\left(\mathrm{BCOC} \_\right.$sm, $\mathrm{NMB}=104 \%$; $\mathrm{BCOC} \_$lg $\mathrm{NMB}=211 \%$ ). It is important to note that the SP2 used by Schwarz et al. (2010a) was configured differently to the instrument used in this study; therefore, the results may not be comparable.

These measurement uncertainties highlight the need for more measurements of the $\mathrm{BC}$ number size distribution at and below $D_{\mathrm{BC}} \sim 100 \mathrm{~nm}$, where most of the number lies. As far as the authors are aware, Schwarz et al. (2010a) have performed the only validation of SP2 measurements of particle number, and their investigation was performed under laboratory conditions. Here we are using SP2 measurements performed under varied ambient conditions and at a range of altitudes. With BC mass concentrations the measurements can be compared with other BC mass-sensitive measurements such as light absorption (McMeeking et al., 2010), to give an indication of how well the SP2 captures the behaviour of atmospheric BC. However, for SP2-measured BC number concentrations there is a lack of instruments available to validate the measurements with.

\subsection{Quantifying the fraction of particles containing BC}

Previous studies have shown that carbonaceous (BC/OC) particles make important contributions to global and regional CCN (e.g. Pierce et al., 2007; Spracklen et al., 2011), the number concentration of which governs the magnitude of the aerosol indirect effect. Although total particle and CCN concentrations have been evaluated in these studies, the number fraction of carbonaceous particles contributing to $\mathrm{CCN}$-sized particles has not been evaluated. In this section, we use the $\mathrm{BC}$-core and total particle number size distributions to evaluate the predicted fraction of particles that contain BC.

The number fraction of $\mathrm{BC}$-containing particles is the ratio of the number concentration of $\mathrm{BC}$ cores to the total (BCand non-BC-containing) particle number concentration. This ratio is calculated over the size range of coated $\mathrm{BC}$ particles. 
(a) D1

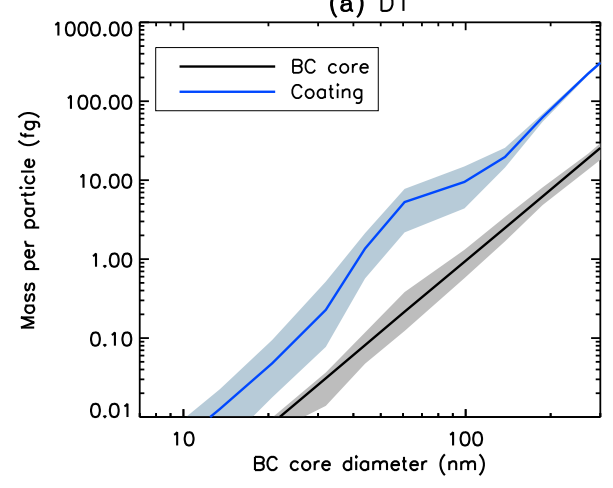

(b) D3

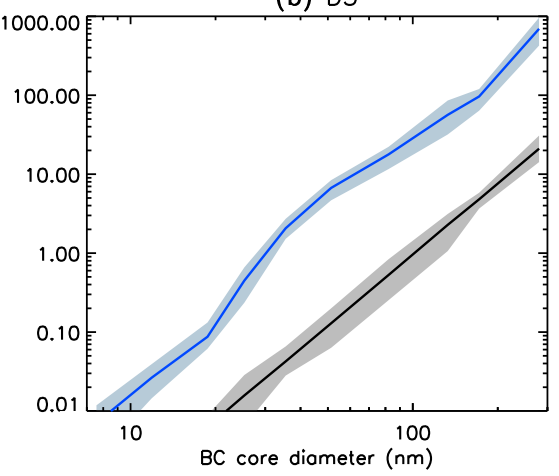

Fig. 9. Modelled BC (black) and coating (blue) mass per particle versus campaign-mean BC core diameter in distributions (a) D1 and (b) D3 (see Table 1). The campaign-mean mass per particle in each size bin is shown by the solid line (model data were averaged over the 12 FAAM aircraft flights shown in Fig. 1). The shading extends from the minimum to the maximum mass per particle in each size bin. A very small fraction of thickly coated BC cores in D3 are not included in this figure so as not to bias the mean coating mass per particle (see discussion in Sect. 4.4). Model results are shown for experiment BCOC_sm (see Table 2).

(a) D1

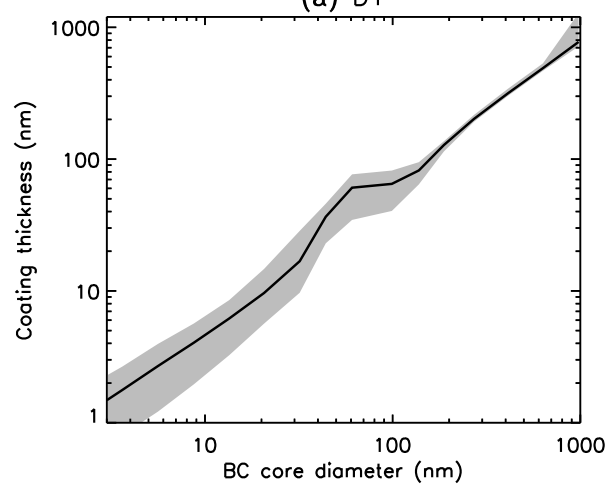

(b) D3

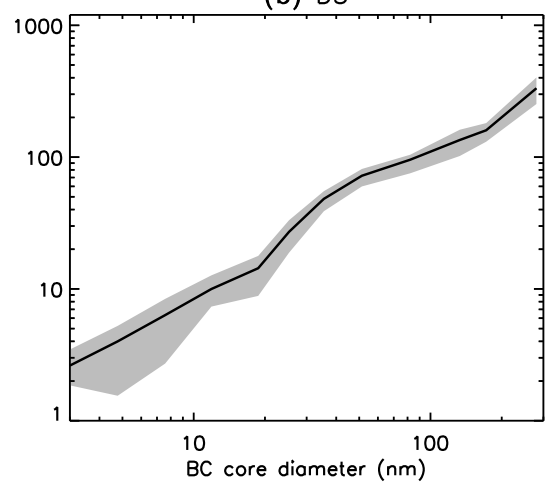

Fig. 10. Modelled coating thickness of non-BC material versus campaign-mean BC core diameter in distributions (a) D1 and (b) D3 (see Table 1). The campaign-mean coating thickness in each size bin is shown by the solid line (model data were averaged over the 12 FAAM aircraft flights shown in Fig. 1). The shading extends from the minimum to the maximum coating thickness in each size bin. As for Fig. 9, a very small fraction of thickly coated BC cores in D3 are not included in this figure so as not to bias the mean coating thickness (see Sect. 4.4). Model results are shown for experiment BCOC_sm (see Table 2).

In the model, $\mathrm{BC}$ cores in the SP2 size range $\left(D_{\mathrm{BC}}=90\right.$ $400 \mathrm{~nm}$ ) correspond to coated particles in the diameter range $\sim 260 \mathrm{~nm}-4.5 \mu \mathrm{m}$ when averaged over all flights. There is some variation in the coated particle diameters between flights due to variations in the mass of non-BC material associated with the particles. The minimum and maximum sizes of coated particles for the campaign period are $D_{\mathrm{p}} \sim 200 \mathrm{~nm}$ and $D_{\mathrm{p}} \sim 10 \mu \mathrm{m}$, respectively. Likewise, the differences in the $\mathrm{BC}$ size distribution in the BCOC_sm and BCOC_lg experiments lead to small differences in the size range of coated $\mathrm{BC}$ particles. Thus, the modelled $\mathrm{BC}$ number fraction, $f_{\mathrm{BC}}$, is calculated for each data point and each model experiment separately according to

$f_{\mathrm{BC}}=\frac{\sum_{90 \mathrm{~nm}}^{400 \mathrm{~nm}}\left(N_{\mathrm{D} 1}+N_{\mathrm{D} 3}\right)}{\sum_{90 \mathrm{~nm}+\text { coat }}^{400 \mathrm{coat}}\left(N_{\mathrm{D} 1}+N_{\mathrm{D} 2}+N_{\mathrm{D} 3}\right)}$, where $N_{\mathrm{D} 1}, N_{\mathrm{D} 2}$ and $N_{\mathrm{D} 3}$ are the number concentrations of particles in distributions D1, D2 and D3, and coat is the contribution to the particle diameter in the model from the non$\mathrm{BC}$ material coating the $\mathrm{BC}$ cores (i.e. the coating thickness).

Figure 10 shows the simulated mean coating thickness of non-BC material (coat; Eq. (2)) versus mean BC core diameter for the campaign period. There is a very low number of $\mathrm{BC}$ cores in D3 $\left(\leq 0.5 \mathrm{~cm}^{-3}\right.$ when averaged over the campaign period) with very thick coatings of non-BC material (mean coat $\sim 0.6-7.2 \mu \mathrm{m}$ ). Since the number concentration of these $\mathrm{BC}$ cores is negligible relative to the particle concentration in the corresponding size bin, their coating thickness is not included in Fig. 10 so as not to bias the mean. However, these particles are included in all calculations of the modelled $\mathrm{BC}$ core mass and number concentrations. These BC cores (with mean $D_{\mathrm{BC}} \sim 30-110 \mathrm{~nm}$ ) originate from the 
large particles in the tail of the coated particle size distribution shown in Fig. 2d (see Sect. 4.1) and Fig. 8. Discounting these particles, the mean coated-particle size range defined by the model would be $D_{\mathrm{p}} \sim 260-1.1 \mu \mathrm{m}$.

In the observations the total particle number concentration is obtained from the size distribution measured by the PCASP instrument (Sect. 2), and the observed BC number fraction $\left(f_{\mathrm{BC} \text {, obs }}\right)$ is calculated according to

$$
f_{\mathrm{BC}, \mathrm{obs}}=\frac{\sum_{90 \mathrm{~nm}}^{400 \mathrm{~nm}}\left(N_{\mathrm{SP} 2}\right)}{\sum_{90 \mathrm{~nm}+\text { coat }}^{400 \mathrm{coat}}\left(N_{\mathrm{PCASP}}\right)},
$$

where $N_{\mathrm{SP} 2}$ is the number concentration of BC cores measured by the SP2 and $N_{\text {PCASP }}$ is the total particle number concentration measured by the PCASP in the size range of coated BC particles. Direct sizing information for the coated particles sampled by the SP2 is unavailable for this campaign period (Sect. 2); thus the observed coating thickness is not known. Therefore, to define the integration limits for the summation in the denominator of Eq. (3), we use the model to provide an estimate of the coated-particle size range. The upper limit of the mean modelled coated-particle size range $(4.5 \mu \mathrm{m})$ is greater than the upper detection limit of the PCASP $(3 \mu \mathrm{m})$, but this has no impact on the derived BC number faction since the number concentration of particles with $D_{\mathrm{p}}>3 \mu \mathrm{m}$ is is negligible in the model $\left(\leq 0.07 \mathrm{~cm}^{-3}\right)$.

The modelled and observed total particle size distributions are shown in Fig. 8 (dashed lines). The modelled campaignmean total particle number concentration is within a factor of 2 of the PCASP observations in the model-defined size range of coated BC particles, which is well within the standard deviation of the measurements. The biases between modelled and observed total particle number concentrations in this size range are shown in Table 5. The NMB between modelled and observed flight-mean number concentrations is $-24 \%$ in the BCOC_lg experiment and $-50 \%$ in the BCOC_sm experiment. The improved agreement in experiment BCOC_lg for modelled and observed total particle number concentrations at the large end of the size distribution is consistent with the results of our analysis of accumulation mode particle number concentrations in Reddington et al. (2011). In this study we found good agreement between GLOMAP modelled number concentrations with $D_{\mathrm{p}}>160 \mathrm{~nm}$ and PCASP measurements made on-board the DLR Falcon aircraft for the same campaign period (NMB -20\%) (Reddington et al., 2011).

An uncertainty in modelled coating thickness will introduce an uncertainty into the calculation of $f_{\mathrm{BC} \text {,obs }}$ (Eq. (3)). Based on the measured and observed total size distributions in Fig. 8 and in Reddington et al. (2011), we estimate the uncertainty in non-BC mass in the size range of coated particles to be a factor of $\sim 2$. This corresponds to a $\sim 26 \%$ uncertainty in the size of coated BC particles. To take into account this uncertainty, we calculate upper and lower limits to the observed $\mathrm{BC}$ number fraction, shown in Table 6, based
Table 5. Normalised mean bias (NMB) between modelled and observed total particle number concentrations $\left(N_{\text {tot }}\right)$ below $2.5 \mathrm{~km}$ a.s.1. for each FAAM aircraft flight and for the whole EUCAARI-LONGREX campaign period (6-24 May 2008). Total particle number concentrations are compared in the size range of coated BC particles defined by the model: BC cores in the SP2 size range correspond to coated $\mathrm{BC}$ particles in the size range of $D_{\mathrm{p}} \sim 260 \mathrm{~nm}-4.5 \mu \mathrm{m}$, averaged over all flights. Model experiments, BCOC_sm and BCOC_lg, are described in Table 2.

\begin{tabular}{llrr}
\hline & \multicolumn{2}{c}{$N_{\text {tot }}$ NMB } \\
\hline Date & Flight & BCOC_sm & BCOC_lg \\
\hline $06 / 05 / 2008$ & B362 & $-76 \%$ & $-57 \%$ \\
$06 / 05 / 2008$ & B363 & $-65 \%$ & $-42 \%$ \\
$08 / 05 / 2008$ & B365 & $-8 \%$ & $45 \%$ \\
$09 / 05 / 2008$ & B367 & $-65 \%$ & $-43 \%$ \\
$10 / 05 / 2008$ & B368 & $23 \%$ & $114 \%$ \\
$10 / 05 / 2008$ & B369 & $-2 \%$ & $78 \%$ \\
$12 / 05 / 2008$ & B3370 & $148 \%$ & $218 \%$ \\
$12 / 05 / 2008$ & B371 & $-24 \%$ & $36 \%$ \\
$13 / 05 / 2008$ & B373 & $-3 \%$ & $32 \%$ \\
$14 / 05 / 2008$ & B374 & $-41 \%$ & $-17 \%$ \\
$21 / 05 / 2008$ & B379 & $-78 \%$ & $-67 \%$ \\
$22 / 05 / 2008$ & B330 & $-72 \%$ & $-57 \%$ \\
\hline $06-22 / 05 / 2008$ & Campaign & $-51 \%$ & $-24 \%$ \\
\hline
\end{tabular}

on minimum and maximum possible PCASP-measured number concentrations within $\pm 26 \%$ of the coated-particle size range. The shape of the PCASP-measured number size distribution (Fig. 8) means that a $26 \%$ shift in the model-defined size range of coated $\mathrm{BC}$ particles can lead to a large change in the derived number concentration of total particles and thus result in a large change in the observed $\mathrm{BC}$ number fraction.

Figure 11 shows normalised frequency distributions of the modelled and observed number fractions of BC-containing particles in the total particle number concentration (with $D_{\mathrm{p}} \gtrsim 260 \mathrm{~nm}$ ) for each flight. The modelled distributions are very narrow, generally centred between a $\mathrm{BC}$ number fraction of 0.8 and 1.0. The frequency distributions of the observations are much broader than predicted by the model, showing a wide range in the derived $\mathrm{BC}$ number fraction, but with the most frequently observed fraction remaining below 0.5 for every flight.

For some flights the observed distributions have long thin tails which extend beyond a fraction of 2.0 (the axes in Fig. 11 have been restricted to a maximum of 2.0 so that the shape of the observed distribution remains clearly visible), which correspond to instances where the SP2-measured number concentration is greater than the PCASP-measured number concentration in the model-defined size range of coated particles. These instances will be partly due to the measurement uncertainty associated with the instruments and partly due to the uncertainty associated with the model definition of the coated-particle size range. If the average 
Table 6. Median modelled and observed number fractions of BC cores $\left(D_{\mathrm{BC}}=90-400 \mathrm{~nm}\right)$ in the total particle number concentration for each flight and for the campaign period. BC number fractions are calculated over the size range of coated $\mathrm{BC}$ particles defined by the model: $\mathrm{BC}$ cores in the SP2 size range correspond to coated particles in the size range of $D_{\mathrm{p}} \sim 260 \mathrm{~nm}-4.5 \mu \mathrm{m}$, averaged over all flights. Because the observed $\mathrm{BC}$ number fraction uses model information for the size range of total particles, estimates are different for the two model experiments, BCOC_sm and BCOC_lg. These experiments are described in Table 2.

\begin{tabular}{llcccc}
\hline & & \multicolumn{5}{c}{ BC number fraction } \\
\hline Date & BCOC_sm model experiment & BCOC_lg model experiment \\
\hline $06 / 05 / 2008$ & B362 & 0.96 & $0.08_{-0.05}^{+0.10}$ & 0.90 & $0.07_{-0.04}^{+0.08}$ \\
$06 / 05 / 2008$ & B363 & 0.94 & $0.15_{-0.09}^{+0.21}$ & 0.94 & $0.14_{-0.09}^{+0.20}$ \\
$08 / 05 / 2008$ & B365 & 0.96 & $0.31_{-0.21}^{+0.48}$ & 0.86 & $0.29_{-0.20}^{+0.48}$ \\
$09 / 05 / 2008$ & B367 & 0.91 & $0.20_{-0.13}^{+0.43}$ & 0.93 & $0.20_{-0.13}^{+0.42}$ \\
$10 / 05 / 2008$ & B368 & 0.98 & $0.31_{-0.21}^{+0.53}$ & 0.93 & $0.32_{-0.23}^{+0.55}$ \\
$10 / 05 / 2008$ & B369 & 0.98 & $0.25_{-0.17}^{+0.44}$ & 0.93 & $0.25_{-0.18}^{+0.45}$ \\
$12 / 05 / 2008$ & B370 & 0.98 & $0.45_{-0.34}^{+0.90}$ & 0.94 & $0.39_{-0.29}^{+0.88}$ \\
$12 / 05 / 2008$ & B371 & 0.97 & $0.13_{-0.09}^{+0.25}$ & 0.94 & $0.15_{-0.10}^{+0.26}$ \\
$13 / 05 / 2008$ & B373 & 0.98 & $0.13_{-0.09}^{+0.23}$ & 0.95 & $0.12_{-0.08}^{+0.21}$ \\
$14 / 05 / 2008$ & B374 & 0.95 & $0.13_{-0.09}^{+0.20}$ & 0.94 & $0.12_{-0.08}^{+0.19}$ \\
$21 / 05 / 2008$ & B379 & 0.97 & $0.08_{-0.05}^{+0.12}$ & 0.94 & $0.08_{-0.05}^{+0.11}$ \\
$22 / 05 / 2008$ & B380 & 0.97 & $0.08_{-0.05}^{+0.14}$ & 0.89 & $0.07_{-0.04}^{+0.12}$ \\
\hline $06-22 / 05 / 2008$ & Campaign & 0.97 & $0.14_{-0.09}^{+0.22}$ & 0.94 & $0.14_{-0.09}^{+0.21}$ \\
\hline
\end{tabular}

observed $\mathrm{BC}$ number fraction for each flight is calculated as a mean over the frequency distribution, the mean value is weighted by these low-frequency, high-value fractions (see the dashed line in Fig. 11). We therefore find that the average observed $\mathrm{BC}$ number fraction is better represented by the median value (see the dot-dashed line in Fig. 11).

The median modelled and observed number fractions of BC-containing particles are shown for each flight in Table 6. The flight-median observed $\mathrm{BC}$ number fraction ranges between $7 \%$ and $45 \%$, with a median fraction of $14 \%$ for the campaign period. In contrast, the model predicts almost all particles with $D_{\mathrm{p}} \gtrsim 260 \mathrm{~nm}$ contain BC cores, with flightmedian $\mathrm{BC}$ number fractions in the range 86-98\%. The median modelled $\mathrm{BC}$ number fraction for the campaign period is almost a factor of 7 larger than the observations in both model experiments (BCOC_lg, $94 \%$; BCOC_sm, $97 \%$ ). The $26 \%$ uncertainty associated with the size range of coated $\mathrm{BC}$ particles leads to an uncertainty in the BC number fraction derived from the observations (Table 6). However, the modelled BC number fraction generally lies well outside this "uncertainty" range, with the exception of one flight (B370), where the upper limit of the median observed BC number fraction exceeds $100 \%$.

The substantial overprediction of the observed BC number fraction results from the positive bias in the predicted $\mathrm{BC}$ particle number concentrations (Sect. 4.3), while the model bias in the predicted total particle number concentration is generally either small or negative (Table 5).

\section{Conclusions and implications}

We have evaluated a global aerosol microphysics model against SP2 measurements of the strongly light-absorbing aerosol component, BC, focussing on the mass and number size distributions and mixing state that are important for quantifying the aerosol direct and indirect effects on the climate. SP2 measurements of the mass and number size distributions of BC were made on-board the FAAM research aircraft from 6 to 24 May 2008, during a period of anticyclonic aged pollution over Europe.

Modelled and observed BC mass concentrations in the detection range of the SP2 ( 90-400 nm BC diameter) agree within the approximate factor of 2 uncertainty in the carbonaceous emission inventory (Bond et al., 2004). However, modelled BC mass and number size distributions were shifted to smaller sizes than the observations, underpredicting the peak modal diameter by a factor of $\sim 2.4-3.2$ in the mass distribution and a factor of $\sim 1.7-2.9$ in the number distribution (the range arising from the uncertainty in the assumed emission size distribution of primary BC particles). The number concentration of BC cores was substantially overpredicted by 

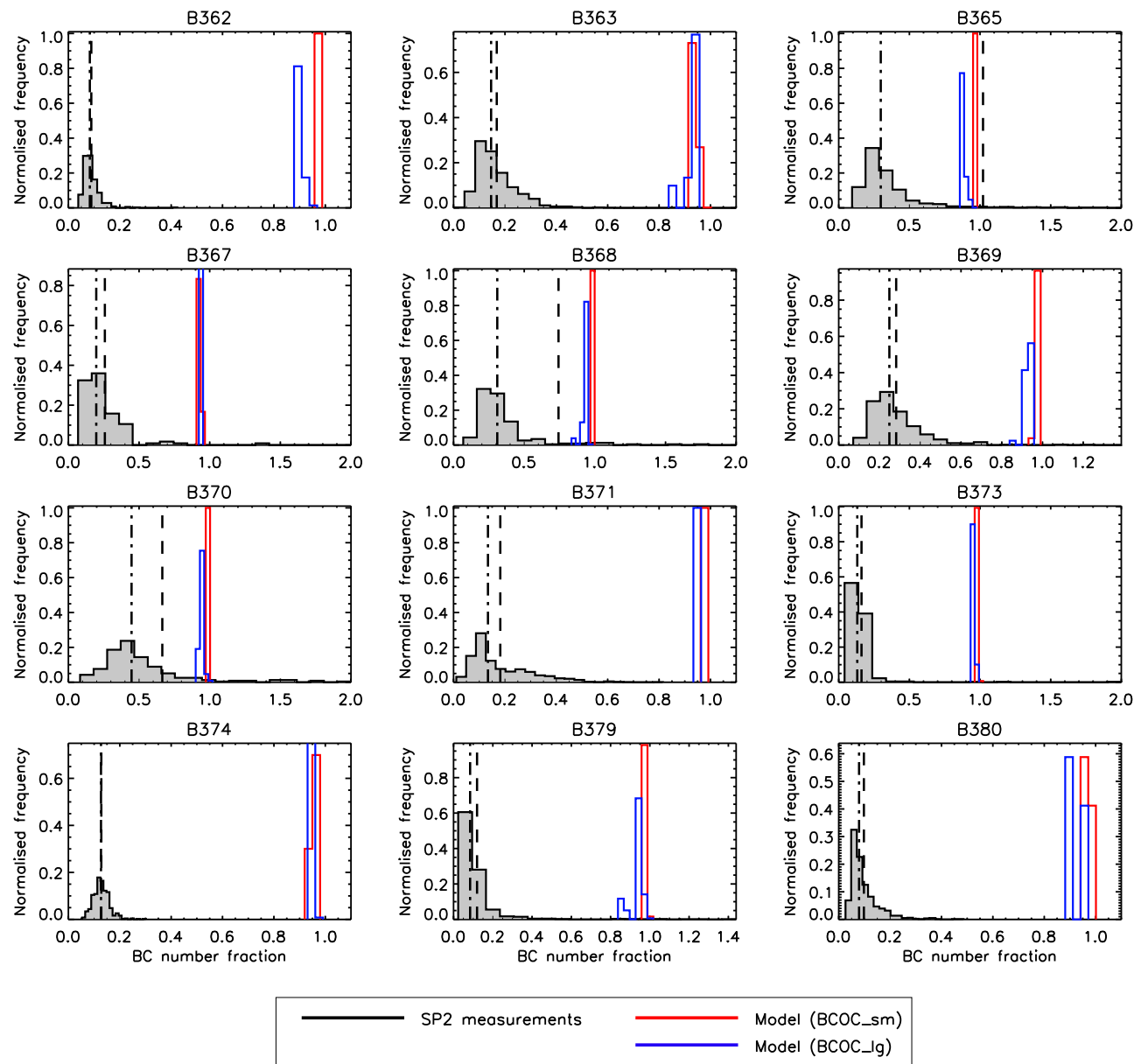

Fig. 11. Normalised histograms of the frequency distribution of modelled (colour) and observed (black) BC number fractions for each valid data point of each flight. The bin size of the modelled distributions is set to 0.03 ; the bin size of the observed distributions depends on the maximum fraction observed for each flight; values are divided into 20 equally spaced bins with the bin size varying between 0.01 and 0.10 . The mean and median observed BC number fractions (calculated over the frequency distribution) for each flight are shown by the dashed and dot-dashed lines, respectively. Model experiments, BCOC_sm and BCOC_lg, are described in Table 2.

the model in the measurement range of the SP2 by a factor of 3.5-5.6. Errors in the size distribution of BC cores result in model overprediction of the number of particles that contain a BC core: the model predicts that almost all particles with dry diameters $\gtrsim 260 \mathrm{~nm}$ contain $\mathrm{BC}(\gtrsim 90 \%)$, while the observations show that on average only $\sim 14 \%$ of particles at these large sizes contain a detectable $\mathrm{BC}$ core. These results suggest there are large errors in the modelled size distribution of the BC component of carbonaceous aerosol.

The discrepancies present in the modelled $\mathrm{BC}$ core size distribution are likely to be related to the treatment of carbonaceous emissions in the model, in particular the assumption of an effective emission size distribution for primary $\mathrm{BC} / \mathrm{OC}$ particles from fossil fuel and biofuel sources. A previous GLOMAP study for the same period has shown that the total particle number size distribution over Europe is very sensitive to the assumed size distribution of the BC/OC particles (Reddington et al., 2011). In this work, we have now shown that the size distribution of the $\mathrm{BC}$ component of the particles is poorly treated in the model. In our model, and in common with most aerosol models, we assume that the $\mathrm{BC}$ and $\mathrm{OC}$ components are homogeneously mixed across the size distribution of emitted carbonaceous combustion particles. However, this assumption is inconsistent with the SP2 observations of BC cores, which suggest that the BC component resides mainly in the larger emitted particles and not in the smaller ones.

There is independent evidence that the homogeneous mixing assumption of emitted $\mathrm{BC} / \mathrm{OC}$ particles with diameters smaller than $\sim 100 \mathrm{~nm}$ is not realistic. Observations in urban environments show that the emission sizes and number concentrations of the BC and POM components can differ considerably (e.g. Baltensperger et al., 2002), suggesting some POM may exist as externally mixed particles (without a detectable $\mathrm{BC}$ core), e.g. emitted from meat cooking as assumed by Riemer et al. (2010). Indications of the number 
size distribution of combustion-generated particles, such as soot, can also be gathered from the non-volatile residues of the particle number size distribution (e.g. Rose et al., 2006; Engler et al., 2007; Birmili et al., 2010). Volatility measurements in the European rural (Engler et al., 2007) and urban (Birmili et al., 2010) background show a consistent mode in the non-volatile number size distribution (with a maximum between $\sim 70$ and $100 \mathrm{~nm}$ ), which is associated with primary soot particles from combustion sources (e.g. Philippin et al., 2004; Rose et al., 2006). Engler et al. (2007) found the number fraction of non-volatile particles (attributed to soot) to be $17 \%$ for diameters $>150 \mathrm{~nm}$ in continental air masses over Europe, similar to what we have estimated from the SP2, but much lower than calculated in the model.

These and previous measurements therefore suggest that the assumption in the model that BC and OC are emitted as internally mixed from fossil fuel sources (with mean particle diameters of 30-60 nm) is incorrect. Rather, the observations suggest that the $\mathrm{BC}$ component exists in only a fraction of the carbonaceous particles, with a peak contribution by mass at around $200 \mathrm{~nm}$ and by number at around $100 \mathrm{~nm}$. The assumptions currently made in the emissions result in an overestimate of the number concentration of $\mathrm{BC}$ particles emitted from combustion sources.

There are other processes in the model in addition to primary emissions, which influence the physical properties of carbonaceous aerosol and may also contribute to the discrepancy in the modelled and observed $\mathrm{BC}$ particle size distributions. For example, self-coagulation (between BC/OC particles) and wet/dry removal processes will act to reduce the number concentrations of $\mathrm{BC}$ cores and alter their size distribution. Condensation of soluble components onto the carbonaceous particles, or "ageing", will influence the wet removal rates of $\mathrm{BC} / \mathrm{OC}$ particles and thus indirectly affect the size distribution of BC cores. However, in the mostly dry anticyclonic conditions of the LONGREX campaign, the modelled BC/OC particle number concentrations below $\sim 1 \mathrm{~km}$ will be most strongly affected by primary emissions. Also, we note that the model captures the total particle size distribution reasonably well (Reddington et al., 2011), which suggests that errors in the $\mathrm{BC}$ distribution have another explanation than microphysics.

Our results suggest that it is the mixing state of the emitted carbonaceous particles that is in error rather than the size distribution of the total particles. That is, BC is wrongly distributed across the carbonaceous size distribution. We reach this conclusion because of the relatively good agreement with the observed total particle number size distribution found here and in Reddington et al. (2011). We found in Reddington et al. (2011) that the size distribution at $\sim 100 \mathrm{~nm}$ was more sensitive to the $\mathrm{BC} / \mathrm{OC}$ emission distribution than to assumptions about nucleated particles. Altering the emitted BC number size distribution to agree with the SP2 observations, but keeping the emitted size distribution of OC the same, would ensure the total number concentration remains com- parable to observations. This set-up would also ensure the model remains consistent with size-segregated aerosol composition measurements at European surface sites that suggest that most particles in the size range $D_{\mathrm{p}} \sim 50-140 \mathrm{~nm}$ consist of carbonaceous material (Putaud et al., 2004; Van Dingenen et al., 2004).

Recent studies using either process models (Riemer et al., 2009, 2010; Zaveri et al., 2010; Oshima et al., 2009a,b) or a sub-model implemented in a global model (Aquila et al., 2011) have made important advances in the representation of $\mathrm{BC}$ mixing state across the particle size distribution. However, since the mixing state of $\mathrm{BC}$ particles upon emission is not well quantified, assumptions still have to be made in these models regarding the initial mixing state of $\mathrm{BC}$ and $\mathrm{POM}$, e.g. assuming fixed BC/POM mass ratios for particles emitted from diesel and gasoline engines (Riemer et al., 2010) or assuming a $100 \% \mathrm{BC}$ mass fraction for freshly emitted BC particles (Oshima et al., 2009a). In addition, although Riemer et al. (2010) and Oshima et al. (2009b) both applied these models in urban scenarios, the assumed parameters of the BC emission size distribution differed considerably: using number median diameters of $50 \mathrm{~nm}(\sigma=1.7)$ and $\sim 107 \mathrm{~nm}$ $(\sigma=1.53)$, respectively.

Future studies are needed to measure the $\mathrm{BC}$ distribution across the emitted particles (rather than just in the ambient atmosphere, as done here), including particle sizes below $\sim 100 \mathrm{~nm}$. Non-volatile measurements are available in the urban background (e.g. Birmili et al., 2010), but the contribution of non-BC non-volatile particles to these measurements is not clear. More information is required on the separate contributions of $\mathrm{BC}$ and $\mathrm{OC}$ to the emitted carbonaceous number size distribution and how the contributions evolve over model grid-box scales. Valuable measurements of the mixing state of EC close to and downwind of sources have recently been made using ATOFMS instruments (e.g. Moffet and Prather, 2009; Healy et al., 2012), but only for sizes larger than $\sim 100 \mathrm{~nm}$.

The incorrect modelling of the distribution of $\mathrm{BC}$ cores across the total size distribution may have important implications for estimates of aerosol absorption optical depth and direct radiative forcing. Several studies have shown that the mixing state of BC strongly influences estimates of direct radiative forcing (e.g. Jacobson, 2001; Schnaiter et al., 2005; Shiraiwa et al., 2008). However, modification of the shape of the BC size distribution would not necessarily have implications for the $\mathrm{CCN}$ potential and indirect effects of carbonaceous particles (which was estimated by Spracklen et al. (2011) to be substantial) because the number concentration and size distribution of POM particles would remain the same. But it is also worth noting that Spracklen et al. (2011) quantified CCN concentrations for particles smaller than those examined here (i.e. $\mathrm{CCN}$ at $0.2 \%$ supersaturation corresponding to dry diameters of approximately $74 \mathrm{~nm}$ ), which in our model would equate to an approximate BC core diameter of $\sim 30 \mathrm{~nm}$. 
The radiative effects of different $\mathrm{BC}$ mixing states should be re-examined to determine the implications for direct forcing due to BC. A similar analysis of observations over other regions and in different conditions, also using different models, will enable us to assess the wider implications of our study. If the mixing state of the particles is found to be important, then effort will be required to model it correctly. The current assumption of a homogeneous BC/OC mixture makes the model relatively easy and numerically inexpensive, while resolving the change in mixing state across the size distribution would be problematic in commonly used modal aerosol models.

Acknowledgements. This research was supported by funding from the EU FP6 European Integrated Project on Aerosol Cloud Climate and Air Quality Interactions (EUCAARI) No. 036833-2 and the NERC ADIENT project. Special thanks to Philip Rosenberg (University of Leeds) for advice on LONGREX PCASP measurements and to Kirsty Pringle (University of Leeds) for technical modelling support.

Edited by: A. Wiedensohler

\section{References}

Andreae, M. O. and Gelencsér, A.: Black carbon or brown carbon? The nature of light-absorbing carbonaceous aerosols, Atmos. Chem. Phys., 6, 3131-3148, doi:10.5194/acp-6-3131-2006, 2006.

Andres, R. J. and Kasgnoc, A. D.: A time-averaged inventory of subaerial volcanic sulfur emissions, J. Geophys. Res., 103, 25251-25261, 1998.

Arnold, S., Chipperfield, M., and Blitz, M.: A three-dimensional model study of the effect of new temperature-dependent quantum yields for acetone photolysis, J. Geophys. Res., 110, D22305, doi:10.1029/2005JD005998, 2005.

Aquila, V., Hendricks, J., Lauer, A., Riemer, N., Vogel, H., Baumgardner, D., Minikin, A., Petzold, A., Schwarz, J. P., Spackman, J. R., Weinzierl, B., Righi, M., and Dall'Amico, M.: MADE-in: a new aerosol microphysics submodel for global simulation of insoluble particles and their mixing state, Geosci. Model Dev., 4, 325-355, doi:10.5194/gmd-4-325-2011, 2011.

Bae, M.-S., Hong, C.-S., Kim, Y. J., Han, J.-S., Moon, K.-J., Kondo, Y., Komazaki, Y., and Miyazaki, Y.: Intercomparison of two different thermal-optical elemental carbons and optical black carbon during ABC-EAREX2005, Atmos. Environ. 41, 2791-2803, 2007.

Baltensperger, U., Streit, N., Weingartner, E., Nyeki, S., Prévôt, A. S. H., Van Dingenen, R., Virkkula, A., Putaud, J. P., Even, A., Ten Brink, H., Blatter, A., Neftel, A., and Gäggeler, H. W.: Urban and rural aerosol characterization of summer smog events during the PIPAPO field campaign in Milan, Italy, J. Geophys. Res., 107, 8193, doi:10.1029/2001JD001292, 2002.

Bauer, S. E., Menon, S., Koch, D., Bond, T. C., and Tsigaridis, K.: A global modeling study on carbonaceous aerosol microphysical characteristics and radiative effects, Atmos. Chem. Phys., 10, 7439-7456, doi:10.5194/acp-10-7439-2010, 2010.
Baumgardner, D., Kok, G., and Raga, G.: Warming of the Arctic lower stratosphere by light absorbing particles, Geophys. Res. Lett., 31, L06117, doi:10.1029/2003GL018883, 2004.

Birmili, W., Heinke, K., Pitz, M., Matschullat, J., Wiedensohler, A., Cyrys, J., Wichmann, H.-E., and Peters, A.: Particle number size distributions in urban air before and after volatilisation, Atmos. Chem. Phys., 10, 4643-4660, doi:10.5194/acp-10-46432010, 2010.

Bond, T. C.: Can warming particles enter global climate discussions?, Environ. Res. Lett., 2, 045030, doi:10.1088/17489326/2/4/045030, 2007.

Bond, T. C. and Bergstrom, R. W.: Light absorption by carbonaceous particles: An investigative review, Aerosol Sci. Technol., 40, 27-67, 382, 2006.

Bond, T. C. and Sun, H.: Can reducing black carbon emissions counteract global warming, Environ. Sci. Technol., 39, 59215926, 2005.

Bond, T., Streets, D. G., Yarber, K. F., Nelson, S. M., Woo, J.H., and Klimont, Z.: A technology-based global inventory of black and organic carbon emissions from combustion, J. Geophys. Res.-Atmos., 109, D14203, doi:10.1029/2003JD003697, 2004.

Bond, T. C., Habib, G., and Bergstrom, R. W.: Limitations in the enhancement of visible light absorption due to mixing state, J. Geophys. Res., 111, D20211, doi:10.1029/2006JD007315, 2006.

Casati, R., Scheer, V., Vogt, R., and Benter, T.: Measurements of nucleation and soot mode particle emission from a diesel passenger car in real world and laboratory in situ dilution, Atmos. Environ., 41, 2125-2135, 2007.

Chen, W.-T., Lee, Y. H., Adams, P. J., Nenes, A., and Seinfeld, J. H.: Will black carbon mitigation dampen aerosol indirect forcing?, Geophys. Res. Lett., 37, L09801, doi:10.1029/2010GL042886, 2010.

Cheng, Y. F., Eichler, H., Wiedensohler, A., Heintzenberg, J., Zhang, Y. H., Hu, M., Herrmann, H., Zeng, L. M., Liu, S., Gnauk, T., Brüggemann, E., and He, L. Y.: Mixing state of elemental carbon and non-light-absorbing aerosol components derived from in situ particle optical properties at Xinken in Pearl River Delta of China, J. Geophys. Res., 111, D20204, doi:10.1029/2005JD006929, 2006.

Cheng, Y. F., Su, H., Rose, D., Gunthe, S. S., Berghof, M., Wehner, B., Achtert, P., Nowak, A., Takegawa, N., Kondo, Y., Shiraiwa, M., Gong, Y. G., Shao, M., Hu, M., Zhu, T., Zhang, Y. H., Wiedensohler, A., Andreae, M. O., and Pöschl, U.: Size-resolved measurement of the mixing state of soot in the megacity Beijing, China: diurnal cycle, aging and parameterization, Atmos. Chem. Phys., 12, 4477-4491, doi:10.5194/acp-12-4477-2012, 2012.

Chipperfield, M.: New version of the TOMCAT/SLIMCAT offline chemical transport model: Intercomparison of stratospheric tracer experiments, Q. J. Roy. Meteor. Soc., 132, 1179-1203, doi:10.1256/qj.05.51, 2006.

Cofala, J., Amann, M., Klimont, Z., and Schopp, W.: Scenarios of World Anthropogenic Emissions of $\mathrm{SO}_{2}, \mathrm{NO}_{\mathrm{x}}$ and $\mathrm{CO}$ up to 2030, Internal report of the Transboundary Air Pollution Programme, International Institute for Applied Systems Analysis, Laxenburg, Austria, 2005.

Cross, E. S., Onasch, T. B., Ahern, A., Wrobel, W., Slowik, J. G., Olfert, J., Lack, D. A., Massoli, P., Cappa, C. D., Schwarz, J. P., Spackman, J. R., Fahey, D. W., Sedlacek, A., Trimborn, A., 
Jayne, J. T., Freedman, A., Williams, L. R., Ng, N. L., Mazzoleni, C., Dubey, M., Brem, B., Kok, G., Subramanian, R., Freitag, S., Clarke, A., Thornhill, D., Marr, L. C., Kolb, C. E., Worsnop, D. R., and Davidovits, P.: Soot Particle Studies - Instrument InterComparison-Project Overview, Aerosol Sci. Technol., 44, 592$611,2010$.

Dentener, F., Kinne, S., Bond, T., Boucher, O., Cofala, J., Generoso, S., Ginoux, P., Gong, S., Hoelzemann, J. J., Ito, A., Marelli, L., Penner, J. E., Putaud, J.-P., Textor, C., Schulz, M., van der Werf, G. R., and Wilson, J.: Emissions of primary aerosol and precursor gases in the years 2000 and 1750 prescribed data-sets for AeroCom, Atmos. Chem. Phys., 6, 4321-4344, doi:10.5194/acp-64321-2006, 2006.

Engler, C., Rose, D., Wehner, B., Wiedensohler, A., Brüggemann, E., Gnauk, T., Spindler, G., Tuch, T., and Birmili, W.: Size distributions of non-volatile particle residuals $\left(D_{\mathrm{p}}<800 \mathrm{~nm}\right)$ at a rural site in Germany and relation to air mass origin, Atmos. Chem. Phys., 7, 5785-5802, doi:10.5194/acp-7-5785-2007, 2007.

Forster, P., Ramaswamy, V., Artaxo, P., Berntsen, T., Betts, R., Fahey, D. W., Haywood, J., Lean, J., Lowe, D. C., Myhre, G., Nganga, J., Prinn, R., Raga, G., Schulz, M., and Van Dorland, R.: Changes in Atmospheric Constituents and in Radiative Forcing, in: Climate Change 2007: The Physical Science Basis. Contribution of Working Group I to the Fourth Assessment Report of the Intergovernmental Panel on Climate Change, edited by: Solomon, S., Qin, D., Manning, M., Chen, Z., Marquis, M., Averyt, K. B., Tignor, M., and Miller, H. L., Cambridge University Press, Cambridge, UK and New York, NY, USA, 2007.

Gao, R. S., Schwarz, J. P., Kelly, K. K., Fahey, D. W., Watts, L. A., Thompson, T. L., Spackman, J. R., Slowik, J. G., Cross, E. S., Han, J. H., Davidovits, P., Onasch, T. B., and Worsnop, D. R.: A novel method for estimating light-scattering properties of soot aerosols using a modified single-particle soot photometer, Aerosol Sci. Technol., 41, 125-135, 2007.

Gilardoni, S., Vignati, E., and Wilson, J.: Using measurements for evaluation of black carbon modeling, Atmos. Chem. Phys., 11, 439-455, doi:10.5194/acp-11-439-2011, 2011.

Gong, S., Barrie, L., Blanchet, J.-P., von Salzen, K., Lohmann, U., Lesins, G., Spacek, L., Zhang, L., Girard, E., Lin, H., Leaitch, R., Leighton, H., Chylek, P., and Huang, P.: Canadian aerosol module: A size-segregated simulation of atmospheric aerosol processes for climate and air quality models 1 . Module development, J. Geophys. Res., 108, 4007, doi:10.1029/2001JD002002, 2003.

Grieshop, A. P., Reynolds, C. C. O., Kandlikar, M., and Dowlatabadi, H.: A black-carbon mitigation wedge, Nat. Geosci. 2, 533-534, 2009.

Guenther, A., Hewitt, C., Erickson, D., Geron, C., Graedal, T., Harley, P., Klinger, L., Lerdau, M., McKay, W., Pierce, T., Scholes, B., Steinbrecher, R., Tallamraju, R., Taylor, J., and Zimmerman, P.: A global model of natural volatile organic compound emissions, J. Geophys. Res., 100, 8873-8892, 1995.

Hamburger, T., McMeeking, G., Minikin, A., Birmili, W., Dall'Osto, M., O’Dowd, C., Flentje, H., Henzing, B., Junninen, H., Kristensson, A., de Leeuw, G., Stohl, A., Burkhart, J. F., Coe, H., Krejci, R., and Petzold, A.: Overview of the synoptic and pollution situation over Europe during the EUCAARILONGREX field campaign, Atmos. Chem. Phys., 11, 10651082, doi:10.5194/acp-11-1065-2011, 2011.
Haywood, J. and Boucher, O.: Estimates of the direct and indirect radiative forcing due to tropospheric aerosols: a review, Rev. Geophys., 38, 513-543, 2000.

Healy, R. M., Sciare, J., Poulain, L., Kamili, K., Merkel, M., Müller, T., Wiedensohler, A., Eckhardt, S., Stohl, A., Sarda-Estéve, R., McGillicuddy, E., O'Connor, I. P., Sodeau, J. R., and Wenger, J. C.: Sources and mixing state of size-resolved elemental carbon particles in a European megacity: Paris, Atmos. Chem. Phys., 12, 1681-1700, doi:10.5194/acp-12-1681-2012, 2012.

Hitzenberger, R., Petzold, A., Bauer, H., Ctyroky, P., Pouresmaeil, P., Laskus, L., and Puxbaum, H.: Intercomparison of thermal and optical measurement methods for elemental carbon and black carbon at an urban location. Environ. Sci. Technol., 40, 63776381, 2006.

Holtslag, A. A. M. and Boville, B. A.: Local versus nonlocal boundary-layer diffusion in a global climate model, J. Climate, 6, 1825-1842, 1993.

Ito, A. and Penner, J. E.: Historical emissions of carbonaceous aerosols from biomass and fossil fuel burning for the period 1870-2000, Global Biogeochem. Cy., 19, GB2028, doi:10.1029/2004GB002374, 2005.

Jacobson, M. Z.: Strong radiative heating due to the mixing state of black carbon in atmospheric aerosols, Nature, 409, 695-697, 2001.

Jacobson, M. Z.: Control of fossil-fuel particulate black carbon and organic matter, possibly the most effective way of slowing anthropogenic global warming, J. Geophys. Res. 107, 4410, doi:10.1029/2001JD001376, 2002.

Jacobson, M. Z.: Short-term effects of controlling fossil-fuel soot, biofuel soot and gases, and methane on climate, Arctic ice, and air pollution health, J. Geophys. Res., 115, D14209, doi:10.1029/2009JD013795, 2010.

Jeong, C.-H., Hopke, P. K., Kim, E., and Lee, D.-W.: The comparison between thermal-optical transmittance elemental carbon and Aethalometer black carbon measured at multiple monitoring sites, Atmos. Environ., 38, 5193-5204, 2004.

Kittelson, D. B., Johnson, J., Watts, W., Wei, Q., Drayton, M., Paulsen, D., and Bukowiecki, N.: Diesel aerosol sampling in the atmosphere, Society of Automotive Engineers, Technical Paper Series, No. 2000-01-2212, doi:10.4271/2000-01-2212, 2000.

Kittelson, D. B., Watts, W. F., and Johnson, J. P.: On-road and laboratory evaluation of combustion aerosols - Part 1: Summary of diesel engine results, J. Aerosol Sci., 37, 913-930, 2006.

Kleinman, L. I., Daum, P. H., Lee, Y.-N., Lewis, E. R., Sedlacek III, A. J., Senum, G. I., Springston, S. R., Wang, J., Hubbe, J., Jayne, J., Min, Q., Yum, S. S., and Allen, G.: Aerosol concentration and size distribution measured below, in, and above cloud from the DOE G-1 during VOCALS-REx, Atmos. Chem. Phys., 12, $207-$ 223, doi:10.5194/acp-12-207-2012, 2012.

Koch, D., Schulz, M., Kinne, S., McNaughton, C., and Spackman, J. R.: Evaluation of black carbon estimations in global aerosol models, Atmos. Chem. Phys., 9, 9001-9026, doi:10.5194/acp-99001-2009, 2009.

Koch, D., Balkanski, Y., Bauer, S. E., Easter, R. C., Ferrachat, S., Ghan, S. J., Hoose, C., Iversen, T., Kirkevåg, A., Kristjansson, J. E., Liu, X., Lohmann, U., Menon, S., Quaas, J., Schulz, M., Seland, Ø., Takemura, T., and Yan, N.: Soot microphysical effects on liquid clouds, a multi-model investigation, Atmos. Chem. Phys., 11, 1051-1064, doi:10.5194/acp-11-1051-2011, 2011. 
Kondo, Y., Sahu, L., Moteki, N., Khan, F., Takegawa, N., Liu, X., Koike, M., and Miyakawa, T.: Consistency and traceability of black carbon measurements made by laser-induced incandescence, thermal-optical transmittance, and filter- based photoabsorption techniques, Aerosol Sci. Technol., 45, 295-312, 2011.

Korhonen, H., Carslaw, K. S., Spracklen, D. V., Mann, G. W., and Woodhouse, M. T.: Influence of oceanic dimethyl sulfide emissions on cloud condensation nuclei concentrations and seasonality over the remote Southern Hemisphere oceans: A global model study, J. Geophys. Res.-Atmos., 113, D15204, doi:10.1029/2007JD009718, 2008.

Kuang, C., McMurry, P. H., McCormick, A. V. and EiseleF. L.: Dependence of nucleation rates on sulfuric acid vapor concentration in diverse atmospheric locations, J. Geophys. Res., 113, D10209, doi:10.1029/2007JD009253, 2008.

Kulmala, M., Laaksonen, A., and Pirjola, L.: Parameterizations for sulfuric acid/water nucleation rates, J. Geophys. Res., 103, 83018307, 1998.

Kulmala, M., Asmi, A., Lappalainen, H. K., Carslaw, K. S., Poschl, U., Baltensperger, U., Hov, O., Brenquier, J.-L., Pandis, S. N., Facchini, M. C., Hansson, H.-C., Wiedensohler, A., and O'Dowd, C. D.: Introduction: European Integrated Project on Aerosol Cloud Climate and Air Quality interactions (EUCAARI) - integrated aerosol research from nano to global scales, Atmos. Chem. Phys., 9, 2825-2841, doi:10.5194/acp-9-2825-2009, 2009.

Kulmala, M., Asmi, A., Lappalainen, H. K., Baltensperger, U., Brenguier, J.-L., Facchini, M. C., Hansson, H.-C., Hov, Ø., O'Dowd, C. D., Pöschl, U., Wiedensohler, A., Boers, R., Boucher, O., de Leeuw, G., Denier van der Gon, H. A. C., Feichter, J., Krejci, R., Laj, P., Lihavainen, H., Lohmann, U., McFiggans, G., Mentel, T., Pilinis, C., Riipinen, I., Schulz, M., Stohl, A., Swietlicki, E., Vignati, E., Alves, C., Amann, M., Ammann, M., Arabas, S., Artaxo, P., Baars, H., Beddows, D. C. S., Bergström, R., Beukes, J. P., Bilde, M., Burkhart, J. F., Canonaco, F., Clegg, S. L., Coe, H., Crumeyrolle, S., D’Anna, B., Decesari, S., Gilardoni, S., Fischer, M., Fjaeraa, A. M., Fountoukis, C., George, C., Gomes, L., Halloran, P., Hamburger, T., Harrison, R. M., Herrmann, H., Hoffmann, T., Hoose, C., Hu, M., Hyvärinen, A., Hõrrak, U., Iinuma, Y., Iversen, T., Josipovic, M., Kanakidou, M., Kiendler-Scharr, A., Kirkevåg, A., Kiss, G., Klimont, Z., Kolmonen, P., Komppula, M., Kristjánsson, J.-E., Laakso, L., Laaksonen, A., Labonnote, L., Lanz, V. A., Lehtinen, K. E. J., Rizzo, L. V., Makkonen, R., Manninen, H. E., McMeeking, G., Merikanto, J., Minikin, A., Mirme, S., Morgan, W. T., Nemitz, E., O’Donnell, D., Panwar, T. S., Pawlowska, H., Petzold, A., Pienaar, J. J., Pio, C., Plass-Duelmer, C., Prévôt, A. S. H., Pryor, S., Reddington, C. L., Roberts, G., Rosenfeld, D., Schwarz, J., Seland, Ø., Sellegri, K., Shen, X. J., Shiraiwa, M., Siebert, H., Sierau, B., Simpson, D., Sun, J. Y., Topping, D., Tunved, P., Vaattovaara, P., Vakkari, V., Veefkind, J. P., Visschedijk, A., Vuollekoski, H., Vuolo, R., Wehner, B., Wildt, J., Woodward, S., Worsnop, D. R., van Zadelhoff, G.-J., Zardini, A. A., Zhang, K., van Zyl, P. G., Kerminen, V.-M., S Carslaw, K., and Pandis, S. N.: General overview: European Integrated project on Aerosol Cloud Climate and Air Quality interactions (EUCAARI) - integrating aerosol research from nano to global scales, Atmos. Chem. Phys., 11, 13061-13143, doi:10.5194/acp11-13061-2011, 2011.
Lee, L. A., Pringle, K. J., Reddington, C. L., Mann, G. W., Stier, P., Spracklen, D. V., Pierce, J. R., and Carslaw, K. S.: The magnitude and causes of uncertainty in global model simulations of cloud condensation nuclei, Atmos. Chem. Phys. Discuss., 13, 62956378, doi:10.5194/acpd-13-6295-2013, 2013.

McMeeking, G. R., Hamburger, T., Liu, D., Flynn, M., Morgan, W. T., Northway, M., Highwood, E. J., Krejci, R., Allan, J. D., Minikin, A., and Coe, H.: Black carbon measurements in the boundary layer over western and northern Europe, Atmos. Chem. Phys., 10, 9393-9414, doi:10.5194/acp-10-9393-2010, 2010.

McMeeking, G. R., Good, N., Petters, M. D., McFiggans, G., and Coe, H.: Influences on the fraction of hydrophobic and hydrophilic black carbon in the atmosphere, Atmos. Chem. Phys., 11, 5099-5112, doi:10.5194/acp-11-5099-2011, $2011 \mathrm{a}$.

McMeeking, G. R., Morgan, W. T., Flynn, M., Highwood, E. J., Turnbull, K., Haywood, J., and Coe, H.: Black carbon aerosol mixing state, organic aerosols and aerosol optical properties over the United Kingdom, Atmos. Chem. Phys., 11, 9037-9052, doi:10.5194/acp-11-9037-2011, 2011 b.

Merikanto, J., Spracklen, D. V., Mann, G. W., Pickering, S. J., and Carslaw, K. S.: Impact of nucleation on global CCN, Atmos. Chem. Phys., 9, 8601-8616, doi:10.5194/acp-9-8601-2009, 2009.

Moffet, R. C. and Prather, K. A.: In-situ measurements of the mixing state and optical properties of soot with implications for radiative forcing estimates, PNAS, 106, 11872-11877, doi:10.1073/pnas.0900040106, 2009.

Oshima, N., Koike, M., Zhang, Y., Kondo, Y., Moteki, N., Takegawa, N., and Miyazaki, Y.: Aging of black carbon in outflow from anthropogenic sources using a mixing state resolved model: Model development and evaluation, J. Geophys. Res., 114, D06210, doi:10.1029/2008JD010680, 2009a.

Oshima, N., Koike, M., Zhang, Y., and Kondo, Y.: Aging of black carbon in outflow from anthropogenic sources using a mixing state resolved model: 2. Aerosol optical properties and cloud condensation nuclei activities, J. Geophys. Res., 114, D18202, doi:10.1029/2008JD011681, 2009b.

Philippin, S., Wiedensohler, A., and Stratmann, F.: Measurements of non-volatile fractions of pollution aerosols with an eight-tube volatility tandem differential mobility analyzer (VTDMA-8), J. Aerosol Sci., 35, 185-203, 2004.

Pierce, J. R., Chen, K., and Adams, P. J.: Contribution of primary carbonaceous aerosol to cloud condensation nuclei: processes and uncertainties evaluated with a global aerosol microphysics model, Atmos. Chem. Phys., 7, 5447-5466, doi:10.5194/acp-75447-2007, 2007.

Pierce, J. R. and Adams, P. J.: Uncertainty in global CCN concentrations from uncertain aerosol nucleation and primary emission rates, Atmos. Chem. Phys., 9, 1339-1356, doi:10.5194/acp-91339-2009, 2009.

Putaud, J. P., Raes, F., Van Dingenen, R., Brüggemann, E., Facchini, M. C., Decesari, S., Fuzzi, S., Gehrig, R., Hüglin, C., Laj, P., Lorbeer, G., Maenhaut, W., Mihalopoulos, N., Muller, K., Querol, X., Rodriguez, S., Schneider, J., Spindler, G., tenBrink, H., Torseth, K., and Wiedensohler, A.: A European aerosol phenomenology - 2: chemical characteristics of particulate matter at kerbside, urban, rural and background sites in Europe, Atmos. Environ., 38, 2579-2595, 2004. 
Ram, K., Sarin, M. M., and Tripathi, S. N.: Inter-comparison of thermal and optical methods for determination of atmospheric black carbon and attenuation coefficient from an urban location in northern India, Atmos. Res., 97, 335-342, doi:10.1016/j.atmosres.2010.04.006, 2010.

Ramanathan, V. and Carmichael, G.: Global and regional climate changes due to black carbon, Nat. Geosci., 1, 221-227, 2009.

Reddington, C. L., Carslaw, K. S., Spracklen, D. V., Frontoso, M. G., Collins, L., Merikanto, J., Minikin, A., Hamburger, T., Coe, H., Kulmala, M., Aalto, P., Flentje, H., Plass-Dülmer, C., Birmili, W., Wiedensohler, A., Wehner, B., Tuch, T., Sonntag, A., O’Dowd, C. D., Jennings, S. G., Dupuy, R., Baltensperger, U., Weingartner, E., Hansson, H.-C., Tunved, P., Laj, P., Sellegri, K., Boulon, J., Putaud, J.-P., Gruening, C., Swietlicki, E., Roldin, P., Henzing, J. S., Moerman, M., Mihalopoulos, N., Kouvarakis, G., Ždímal, V., Zíková, N., Marinoni, A., Bonasoni, P., and Duchi, R.: Primary versus secondary contributions to particle number concentrations in the European boundary layer, Atmos. Chem. Phys., 11, 12007-12036, doi:10.5194/acp-11-12007-2011, 2011.

Riemer, N., West, M., Zaveri, R. A., and Easter, R. C.: Simulating the evolution of soot mixing state with a particleresolved aerosol model, J. Geophys. Res., 114, D09202, doi:10.1029/2008JD011073, 2009.

Riemer, N., West, M., Zaveri, R., and Easter, R.: Estimating black carbon aging time-scales with a particle-resolved aerosol model, J. Aerosol Sci., 41, 143-158, 2010.

Rose, D., Wehner, B., Ketzel, M., Engler, C., Voigtländer, J., Tuch, T., and Wiedensohler, A.: Atmospheric number size distributions of soot particles and estimation of emission factors, Atmos. Chem. Phys., 6, 1021-1031, doi:10.5194/acp-6-1021-2006, 2006.

Rose, D., Gunthe, S. S., Su, H., Garland, R. M., Yang, H., Berghof, M., Cheng, Y. F., Wehner, B., Achtert, P., Nowak, A., Wiedensohler, A., Takegawa, N., Kondo, Y., Hu, M., Zhang, Y., Andreae, M. O., and Pöschl, U.: Cloud condensation nuclei in polluted air and biomass burning smoke near the mega-city Guangzhou, China - Part 2: Size-resolved aerosol chemical composition, diurnal cycles, and externally mixed weakly $\mathrm{CCN}$-active soot particles, Atmos. Chem. Phys., 11, 2817-2836, doi:10.5194/acp-112817-2011, 2011.

Rypdal, K., Rive, N., Berntsen, T. K., Klimont, Z., Mideksa, T. K., Myhre, G., and Skeie, R. B.: Costs and global impacts of black carbon abatement strategies, Tellus, 61B, 625-641, 2009.

Schaap, M., Van Der Gon, H. A. C. D., Dentener, F. J., Visschedijk, A. J. H., Van Loon, M., ten Brink, H. M., Putaud, J.-P., Guillaume, B., Liousse, C., and Builtjes, P. J. H.: Anthropogenic black carbon and fine aerosol distribution over Europe, J. Geophys. Res., 109, D18207, doi:10.1029/2003JD004330, 2004.

Schnaiter, M., C. Linke, O. Mohler, K.-H. Naumann, H. Saathoff, R. Wagner, U. Schurath, and B. Wehner: Absorption amplification of black carbon internally mixed with secondary organic aerosol, J. Geophys. Res., 110, D19204, doi:10.1029/2005JD006046, 2005.

Schulz, M., Textor, C., Kinne, S., Balkanski, Y., Bauer, S., Berntsen, T., Berglen, T., Boucher, O., Dentener, F., Guibert, S., Isaksen, I. S. A., Iversen, T., Koch, D., Kirkevåg, A., Liu, X., Montanaro, V., Myhre, G., Penner, J. E., Pitari, G., Reddy, S., Seland, $\varnothing$. ., Stier, P., and Takemura, T.: Radiative forcing by aerosols as derived from the AeroCom present-day and pre-industrial simu- lations, Atmos. Chem. Phys., 6, 5225-5246, doi:10.5194/acp-65225-2006, 2006.

Schwarz, J. P., Gao, R. S., Fahey, D. W., Thomson, D. S., Watts, L. A., Wilson, J. C., Reeves, J. M., Darbeheshti, M., Baumgardner, D. G., Kok, G. L., Chung, S. H., Schulz, M., Hendricks, J., Lauer, A., Kaercher, B., Slowik, J. G., Rosenlof, K. H., Thompson, T. L., Langford, A. O., Loewenstein, M., and Aikin, K. C.: Single-particle measurements of midlatitude black carbon and light-scattering aerosols from the boundary layer to the lower stratosphere, J. Geophys. Res.-Atmos., 111, D16207, doi:10.1029/2006JD007076, 2006.

Schwarz, J. P., Spackman, J. R., Fahey, D. W., Gao, R. S., Lohmann, U., Stier, P., Watts, L. A., Thomson, D. S., Lack, D. A., Pfister, L., Mahoney, M. J., Baumgardner, D., Wilson, J. C., and Reeves, J. M.: Coatings and their enhancement of black carbon light absorption in the tropical atmosphere, J. Geophys. Res.-Atmos., 113, D03203, doi:10.1029/2007JD009042, 2008.

Schwarz, J. P., Spackman, J. R., Gao, R. S., Perring, a. E., Cross, E., Onasch, T. B., Ahern, a., Wrobel, W., Davidovits, P., Olfert, J., Dubey, M. K., Mazzoleni, C., and Fahey, D. W.: The Detection Efficiency of the Single Particle Soot Photometer, Aerosol Sci. Technol., 44, 612-628, doi:10.1080/02786826. 2010.481298, 2010a.

Schwarz, J. P., Spackman, J. R., Gao, R. S., Watts, L. A., Stier, P., Schulz, M., Davis, S. M., Wofsy, S. C., and Fahey, D. W.: Global-scale black carbon profiles observed in the remote atmosphere and compared to models, Geophys. Res. Lett., 37, L18812, doi:10.1029/2010GL044372, 2010b.

Shiraiwa, M., Kondo, Y., Moteki, N., Takegawa, N., Miyazaki, Y., and Blake, D. R.: Evolution of mixing state of black carbon in polluted air from Tokyo, Geophys. Res. Lett., 34, L16803, doi:10.1029/2007GL029819, 2007.

Shiraiwa, M., Kondo, Y., Moteki, N., Takegawa, N., Sahu, L. K., Takami, A., Hatakeyama, S., Yonemura, S., and Blake, D. R.: Radiative impact of mixing state of black carbon aerosol in Asian outflow, J. Geophys. Res.-Atmos., 113, D24210, doi:10.1029/2008JD010546, 2008.

Sihto, S.-L., Kulmala, M., Kerminen, V. M., Dal Maso, M., Petäjä, T., Riipinen, I., Korhonen, H., Arnold, F., Janson, R., Boy, M., Laaksonen, A., and Lehtinen, K. E. J.: Atmospheric sulphuric acid and aerosol formation: implications from atmospheric measurements for nucleation and early growth mechanisms, Atmos. Chem. Phys., 6, 4079-4091, doi:10.5194/acp-6-4079-2006, 2006.

Slowik, J. G., Cross, E., Han, J. -H., Davidovits, P., Onasch, T. B., Jayne, J. T., Williams, L. R., Canagaranata, M. R., Worsnop, D. R., Chakrabarty, R. K., Mossümller, H., Arnott, W. P., Schwarz, J. P., Gao, R. -S., Fahey, D. W., Kok, G. L., and Petzold, A.: An Inter-Comparison of Instruments Measuring Black Carbon Content of Soot Particles, Aerosol Sci. Technol., 41, 295-314, 2007.

Spracklen, D., Carslaw, K., Kulmala, M., Kerminen, V.-M., Sihto, S.-L., Riipinen, I., Merikanto, J., Mann, G., Chipperfield, M., Wiedensohler, A., Birmili, W., and Lihavainen, H.: Contribution of particle formation to global cloud condensation nuclei concentrations, Geophys. Res. Lett., 35, L06808, doi:10.1029/2007GL033038, 2008.

Spracklen, D. V., Pringle, K. J., Carslaw, K. S., Chipperfield, M. P., and Mann, G. W.: A global off-line model of size- 
resolved aerosol microphysics: I. Model development and prediction of aerosol properties, Atmos. Chem. Phys., 5, 22272252, doi:10.5194/acp-5-2227-2005, 2005a.

Spracklen, D. V., Pringle, K. J., Carslaw, K. S., Chipperfield, M. P., and Mann, G. W.: A global off-line model of size-resolved aerosol microphysics: II. Identification of key uncertainties, Atmos. Chem. Phys., 5, 3233-3250, doi:10.5194/acp-5-3233-2005, 2005b.

Spracklen, D. V., Carslaw, K. S., Kulmala, M., Kerminen, V.-M., Mann, G. W., and Sihto, S.-L.: The contribution of boundary layer nucleation events to total particle concentrations on regional and global scales, Atmos. Chem. Phys., 6, 5631-5648, doi:10.5194/acp-6-5631-2006, 2006.

Spracklen, D. V., Carslaw, K. S., Merikanto, J., Mann, G. W., Reddington, C. L., Pickering, S., Ogren, J. A., Andrews, E., Baltensperger, U., Weingartner, E., Boy, M., Kulmala, M., Laakso, L., Lihavainen, H., Kivekäs, N., Komppula, M., Mihalopoulos, N., Kouvarakis, G., Jennings, S. G., O’Dowd, C., Birmili, W., Wiedensohler, A., Weller, R., Gras, J., Laj, P., Sellegri, K., Bonn, B., Krejci, R., Laaksonen, A., Hamed, A., Minikin, A., Harrison, R. M., Talbot, R., and Sun, J.: Explaining global surface aerosol number concentrations in terms of primary emissions and particle formation, Atmos. Chem. Phys., 10, 4775-4793, doi:10.5194/acp-10-4775-2010, 2010.

Spracklen, D. V., Carslaw, K. S., Pöschl, U., Rap, A., and Forster, P. M.: Global cloud condensation nuclei influenced by carbonaceous combustion aerosol, Atmos. Chem. Phys., 11, 9067-9087, doi:10.5194/acp-11-9067-2011, 2011.

Stephens, M., Turner, N., and Sandberg, J.: Particle identification by laser-induced incandescence in a solid-state laser cavity, Appl. Optics, 42, 3726-3736, 2003.

Stevens, R. G., Pierce, J. R., Brock, C. A., Reed, M. K., Crawford, J. H., Holloway, J. S., Ryerson, T. B., Huey, L. G., and Nowak, J. B.: Nucleation and growth of sulfate aerosol in coal-fired power plant plumes: sensitivity to background aerosol and meteorology, Atmos. Chem. Phys., 12, 189-206, doi:10.5194/acp12-189-2012, 2012.

Stier, P., Feichter, J., Kinne, S., Kloster, S., Vignati, E., Wilson, J., Ganzeveld, L., Tegen, I., Werner, M., Balkanski, Y., Schulz, M., Boucher, O., Minikin, A., and Petzold, A.: The aerosol-climate model ECHAM5-HAM, Atmos. Chem. Phys., 5, 1125-1156, doi:10.5194/acp-5-1125-2005, 2005.

Stier, P., Feichter, J., Kloster, S., Vignati, E., and Wilson, J.: Emission-induced nonlinearities in the global aerosol system: results from the ECHAM5-HAM aerosol-climate model, J. Climate, 19, 3845-3862, 2006. ten Brink, H., Maenhaut, W., Hitzenberger, R., Gnauk, T., Spindler, G., Even, A., Chi, X., Bauer, H., Puxbaum, H., Putaud, J. P., Tursic, J., and Berner, A.: INTERCOMP2000: The comparability of methods in use in Europe for measuring the carbon content of aerosol, Atmos. Environ., 38, 6507-6519, 2004.

Textor, C., Schulz, M., Guibert, S., Kinne, S., Balkanski, Y., Bauer, S., Berntsen, T., Berglen, T., Boucher, O., Chin, M., Dentener, F., Diehl, T., Easter, R., Feichter, H., Fillmore, D., Ghan, S., Ginoux, P., Gong, S., Grini, A., Hendricks, J., Horowitz, L., Huang, P., Isaksen, I., Iversen, I., Kloster, S., Koch, D., Kirkevåg, A., Kristjansson, J. E., Krol, M., Lauer, A., Lamarque, J. F., Liu, X., Montanaro, V., Myhre, G., Penner, J., Pitari, G., Reddy, S., Seland, $\emptyset$., Stier, P., Takemura, T., and Tie, X.: Analysis and quantification of the diversities of aerosol life cycles within AeroCom, Atmos. Chem. Phys., 6, 1777-1813, doi:10.5194/acp-6-1777-2006, 2006.

van der Werf, G. R., Randerson, J. T., Collatz, G. J., and Giglio, L.: Carbon emissions from res in tropical and subtropical ecosystems, Global Change Biol., 9, 547-562, 2003.

Van Dingenen, R., Raes, F., Putaud, J.-P., Baltensperger, U., Charron, A., Facchini, M. C., Decesari, S., Fuzzi, S., Gehrig, R., Hansson, H.-C., Harrison, R. M., Hüglin, C., Jones, A. M., Laj, P., Lorbeer, G., Maenhaut, W., Palmgren, F., Querol, X., Rodriguez, S., Schneider, J., ten Brink, H., Tunved, P., Tørseth, K., Wehner, B., Weingartner, E., Wiedensohler, A., and Wåhlin, P.: A European aerosol phenomenology - 1: physical characteristics of particulate matter at kerbside, urban, rural and background sites in Europe, Atmos. Environ., 38, 2561-2577, 2004.

Vignati, E., Karl, M., Krol, M., Wilson, J., Stier, P., and Cavalli, F.: Sources of uncertainties in modelling black carbon at the global scale, Atmos. Chem. Phys., 10, 2595-2611, doi:10.5194/acp-102595-2010, 2010.

Wang, J., Cubison, M. J., Aiken, A. C., Jimenez, J. L., and Collins, D. R.: The importance of aerosol mixing state and size-resolved composition on $\mathrm{CCN}$ concentration and the variation of the importance with atmospheric aging of aerosols, Atmos. Chem. Phys., 10, 7267-7283, doi:10.5194/acp-10-7267-2010, 2010.

Zaveri, R. A., J. C. Barnard, R. C. Easter, N. Riemer, and M. West: Particle-resolved simulation of aerosol size, composition, mixing state, and the associated optical and cloud condensation nuclei activation properties in an evolving urban plume, J. Geophys. Res., 115, D17210, doi:10.1029/2009JD013616, 2010.

Zuberi, B., K. S. Johnson, G. K. Aleks, L. T. Molina, M. J. Molina, and A. Laskin: Hydrophilic properties of aged soot, Geophys. Res. Lett., 32, L01807, doi:10.1029/2004GL021496, 2005. 